\title{
PRAVNA MISAO HERMANNA U. KANTOROWICZA I VRIJEME NACIONALSOCIJALIZMA
}

Izv. prof. dr. sc. Ivana Tucak*
UDK: 340.11:329.18 Kantorowicz, H.

340.124:329.18 Kantorowicz, H.

DOI: 10.3935/zpfz.69.56.04

Pregledni znanstveni rad

Primljeno: kolovoz 2019.

Cilj ovog rada propitivanje je uloge antiformalističke kritike prava Hermana Kantorowicza, jednog od najistaknutijih pripadnika pokreta slobodnog prava (Freirechtsbewegung), u njemačkoj pravnoj teoriji i praksi u vrijeme nacionalsocijalizma. Pripadnici ovog pokreta isticali su nužnost postojanja pravnih praznina, pozivali suce da napuste pravni pozitivizam/formalizam te ga zamjene sustavom koji uzima u obzir društvene okolnosti u kojima pravni spor nastaje te načelo pravednosti. Niz suvremenih autora posvetio se pitanju jesu li te ideje, koje su zastupali Kantorowicz i ostali pripadnici ovog pokreta, na određeni način otvorile vrata za ono što su u nacističkoj Njemačkoj, od 1933. do 1945. godine, činili njemački suci, odnosno jesu li postavile temelje za "pravni teror" koji je obilježio to razdoblje. Rad je podijeljen $u$ dva dijela. Prvi dio rada propituje temeline ideje o pravu, pravnoj znanosti $i$ ulozi sudaca koje je Kantorowicz iznio u Borbi za pravnu znanost. Drugi dio istražuje niz argumenata iz članaka objavljenih u eminentnim pravnim časopisima u prilog ili protiv optužbi usmjerenih na Kantorowicza i pokret slobodnog prava.

Ključne riječi: slobodno pravo, prirodno pravo, pravni pozitivizam, pojmovna jurisprudencija, pravne praznine

\footnotetext{
Dr. sc. Ivana Tucak, izvanredna profesorica Pravnog fakulteta Sveučilišta Josipa Jurja Strossmayera u Osijeku, Stjepana Radića 13, Osijek; itucak@pravos.hr;

ORCID ID: orcid.org/0000-0001-9694-2315
} 


\section{UVOD}

Na prijelazu iz 19. u 20. stoljeće u Njemačkom Carstvu pojavio se Pokret slobodnog prava (Freirechtsbewegung), čiji su pripadnici isticali postojanje praznina u zakonodavnim tekstovima, pozivali suce da napuste pravni pozitivizam / formalizam ili, kako to slikovito opisuje Markus Dirk Dubber, da se oslobode njegovih okova te tumače pravo u skladu s vlastitim osjećajem za pravednost koji bi trebao odražavati narodni osjećaj pravednosti. ${ }^{1}$ Cilj ovog rada propitivanje je antiformalističke kritike prava Hermana Kantorowicza, jednog od najistaknutijih pripadnika ovog pokreta, čiji je utjecaj vidljiv ne samo u pravnoj znanosti nego i u sudskoj praksi. U svojoj knjizi Borba za pravnu znanost, objavljenoj 1906. pod pseudonimom Gnavius Flavius, Kantorowicz je pokretu dao ime te izričito odbacio dotad vladajuće teze o mehaničkoj i neznatnoj ulozi sudaca u primjeni prava. ${ }^{2}$ Premda Kantorowicz nije vidio nužnu povezanost između sudske kreativnosti i sudske arbitrarnosti ${ }^{3}$, niz autora posvetio se pitanju jesu li Kantorowicz i ostali pripadnici ovog pokreta, na određeni način, otvorili vrata za ono što su u nacističkoj Njemačkoj, od 1933. do 1945. godine, činili njemački suci. Autori propituju jesu li ideje pokreta slobodnog prava postavile temelje za

1 Dubber, M. D., Judicial Positivism and Hitler's Injustice, Columbia Law Review, vol. 93, 1993., str. 1819 - 1820.

Kantorowicz među pripadnicima ovog Pokreta u Francuskoj izričito navodi ime F. Gényja, a u Austriji i Njemačkoj sljedeća imena: E. Ehrlich, E. Fuchs, J. Kohler, M. E. Mayer, G. Radbruch, Th. Sternberg i E. Zitelmann. Vidi Kantorowicz, H., Some Rationalism About Realism, Yale Law Journal, vol. 43, 1934., str. 1241.

Detaljnije o spomenutim pripadnicima Pokreta slobodnog prava vidi u članku: Foulkes, A. S., On the German Free Law School (Freirechtsschule), ARSP: Archiv für Rechts- und Sozialphilosophie / Archives for Philosophy of Law and Social Philosophy, vol. 55, br. 3, 1969., str. $367-417$.

Kantorowiczeve ideje bile su predmet dugogodišnjeg znanstvenog istraživanja jednog od vodećih hrvatskih pravnih teoretičara Zorana Pokrovca, čija je opsežna doktorska disertacija od 1300 stranica, uz 600 naslova korištene literature, 2018. godine objavljena u izdanju Naklade Breza. Vidi Pokrovac, Z., Hermann U. Kantorowicz i slobodnopravni pokret, Naklada Breza, Zagreb, 2018.

Svi su prijevodi tekstova inozemnih autora na hrvatski jezik u ovom članku, ako nije drukčije naznačeno, autorovi.

2 Grosswald Curran, V., Fear of Formalism: Indications from the Fascist Period in France and Germany of Judicial Methodology's Impact on Substantive Law, Cornell International Law Journal, vol. 35, br. 1, 2001., str. 157. Vidi Kantorowicz, H., Borba za pravnu nauku, Dosije, Beograd, 2006.

3 Grosswald Curran, V., Rethinking Hermann Kantorowicz: Free Law, American Legal Realism and the Legacy of Anti Formalism, u: Riles, A. (ed.), Rethinking the Masters of Comparative Law, Hart, Oxford, Portland, 2001., str. 78. 
"pravni teror", odnosno jesu li odigrale ulogu u "fanatičnoj nepravdi” njemačkih sudova. ${ }^{4}$ Prožeti idejama kako promijeniti i unaprijediti sudsku metodologiju, priznajući nužnost postojanja pravnih praznina i diskrecijskih ovlasti sudaca te s težnjom da kreativnost sudaca instrumentaliziraju radi poboljšanja prava ${ }^{5}$, pripadnici pokreta sami su imali demokratske ideale. ${ }^{6}$ Međutim, postavlja se pitanje nije li metodologija koju su oni predlagali opasnija i štetnija od one protiv koje su se borili.

Rad je podijeljen u dva dijela. Prvi dio rada propituje temeljne ideje o pravu, pravnoj znanosti i ulozi sudaca koje je Kantorowicz iznio u Borbi za pravnu znanost. Drugi dio istražuje niz argumenata iz suvremene rasprave u prilog ili protiv optužbi usmjerenih na Kantorowicza i pokret slobodnog prava u vezi s njihovom odgovornosti za postupanje njemačkih sudaca za vrijeme nacionalsocijalizma. Članak ovdje slijedi put koji je prošla Vivian Grosswald Curran te kritički preispituje njezine zaključke u vezi s tim.

\section{BORBA ZA PRAVNU ZNANOST}

U vrijeme kada pripadnici pokreta slobodnog prava stupaju na scenu u kontinentalnoj Europi pravni pozitivizam bio je vodeća pravna teorija. Budući da sam pojam nije jednoznačan, na ovom je mjestu važno pojasniti njegovo značenje. U 19. stoljeću "pozitivistički element" obilježio je njemačku pravnu znanost. ${ }^{7}$ Korijeni pojmovne jurisprudencije (Begriffsjurisprudenz ili Konstruktionsjurisprudenz) nalaze se u povijesnopravnoj školi F. C. von Savignyja ${ }^{8}$, "koja je osnovala novu, sustavnu znanost o privatnom pravu sa sviješću o metodičkim razmatranjima". ${ }^{9}$ Povijesnopravna škola isticala je povijesna ograničenja prava te

$4 \quad$ Ibid., str. 68.

5 Joerges, C., History as Non-History: Points of Divergence and Time Lags between Friedrich Kessler and German Jurisprudence, The American Journal of Comparative Law, vol. 42, br. 1, 1994., str. 186 - 187.

6 Vidi Schmidt, K. I., Law, Modernity, Crisis: German Free Lawyers, American Legal Realists, and the Transatlantic Turn to 'Life,' 1903-1933, German Studies Review, vol. 39, br. 1, 2016., str. 135.

7 Reimann, M., Nineteenth Century German Legal Science, Boston College Law Review, vol. 31, 1990., str. 880.

8 Fasso, G., Istorija filozofije prava, CID, Univerzitet Mediteran, Podgorica, 2007., str. 550; Kantorowicz, op. cit. u bilj. 2, str. 27.

9 Ott, W.; Buob, F., Did Legal Positivism Render German Jurists Defenceless During the Third Reich?, Social \& Legal Studies, vol. 2, br. 1, 1993., str. 95; Reimann, op. cit. u bilj. 7, str. 880 . 
se nalazila u opoziciji prema prirodnom pravu, čime je otvoren put nastanku i vladajućoj ulozi pozitivizma u devetnaestostoljetnoj Njemačkoj. ${ }^{10}$ Kako to ističe Kantorowicz, povijesnopravna škola mjesto je nastanka pojmovne jurisprudencije. ${ }^{11}$ No, neovisno o njezinim korijenima, kraj puta joj je u "apstraktnosti" i "antihistoricizmu". ${ }^{12}$ Savignyevi nasljednici nadišli su njegovu "izvornu povijesnu teoriju prava"13: njihova metoda je ahistorijska u smislu da nisu uzimali u obzir povijesnu dimenziju prava; "izolirali su temeljne pojmove u njihovoj čistoći, organizirali ih logički, i stvorili sustav koji je bez praznina i samoreproduktivan". ${ }^{14}$ Pojmovna jurisprudencija u verzijama oba svoja najznačajnija predstavnika Georga Friedricha Puchte i Rudolfa von Jheringa "svela je pravo na igru indukcije i dedukcije. Znanstvena istina i tako autoritet znanstvenog pravnog pravila nije ovisio o njegovoj povijesnoj dokumentiranosti, praktičnom smislu ili društvenoj koristi, nego isključivo o njegovoj logičkoj povezanosti s cjelokupnim sustavom. Pravo više nije bilo proizvod povijesti, nego stvorenje logike". ${ }^{15}$ Konceptualna metoda obećala je pravnicima učiniti pravno rasuđivanje predvidljivim i slobodnim od svih obzira izvan pravnog sustava ${ }^{16}$, socijalnih, ekonomskih, moralnih ili političkih. ${ }^{17}$

Devetnaestostoljetna pravna znanost postavila je "domenu privatnog prava u ruke znanstveno obučenih pravnika". ${ }^{18}$ Završetkom procesa kodifikacija na kraju 19. stoljeća državno zakonodavstvo preuzelo je primat. ${ }^{19}$ Pojmovnu jurisprudenciju postupno je zamijenio pravni pozitivizam (Gesetzespositivismus) "prema kojemu je sveukupno pravo kao cjelina bilo identično državnom pravu donesenom u obliku propisanim ustavom". ${ }^{20}$

10 Zimmermann, A., Legislating Evil: The Philosophical Foundations of the Nazi Legal System, International Trade \& Business Law Review, vol. 13, 2010., str. 232.

11 Kantorowicz, op. cit. u bilj. 2, str. 27. Guido Fasso ističe da je do toga došlo putem pandektistike (Pandektenwissenschaft). Fasso, op. cit. u bilj. 8, str. 550. O Kantorowiczevoj kritici pojmovne jurisprudencije vidi Pokrovac, op. cit. u bilj. 1, str. 187 $-193$.

12 Fasso, op. cit. u bilj. 8, str. 550.

13 Reimann, op. cit. u bilj. 7, str. 859.

14 Ibid., str. 859, 880.

15 Ibid., str. 864.

16 Ibid., str. 865.

17 Ott; Buob, op. cit. u bilj. 9, str. 95.

18 Ibid.

19 Ibid.

20 Ibid. 
Tako je na početku 20. stoljeća izraz "pravni pozitivizam" ponajprije označavao pravnoteorijski smjer koji priznaje status prava samo normama suverene vlasti. ${ }^{21}$ Kao što to ističe Fasso, "pozitivnost" na koju se pravni pozitivizam odnosi jest "formalna pozitivnost normi". Postavila ih je (positum) ustanova kojoj je dana isključiva moć stvaranja prava. ${ }^{22}$ Pravni pozitivizam i formalizam bili su sinonimi. Pozitivisti su portretirali zakonsko pravo kao zatvoren sustav bez pravnih praznina. ${ }^{23}$ Stav o ulozi suca bio je strog. Prevladavalo je uvjerenje da je pravo potpuno sadržano u zakonskim tekstovima, a jedina zadaća suca jest da ga primijeni. ${ }^{24}$ Potpuni izraz dogme o nepostojanju pravnih praznina predstavljao je članak 4. francuskog Građanskog zakonika (Code civile, 1804.). Prema ovom članku, sudac koji odbije donijeti presudu pod izlikom da ne postoji zakonodavni tekst koji uređuje sporno pitanje, ili je on nejasan, može biti procesuiran zbog "uskrate prava". ${ }^{25}$

U Njemačkoj, u kojoj je Kantorowicz djelovao, početkom 20. stoljeća činilo se da se pravni formalizam nalazi na svom vrhuncu. ${ }^{26}$ Dana 1. siječnja 1900. godine na snagu je stupio njemački Građanski zakonik (Bürgerliches Gesetzbuch, BGB), koji je slavljen kao rezultat dugotrajnih napora i pomnih razmatranja te je smatran najsavršenijim proizvodom pravne misli jedne nacije. ${ }^{27}$

Kantorowicz i njegovi "suborci” željeli su ustoličiti novu pravnu metodologiju. Isticali su nedostatke vladajuće primjene prava u 19. stoljeću te zagovarali razvitak klase kreativnih sudaca. ${ }^{28}$ Svoje su postavke pripadnici pokreta podupirali i

${ }^{21} \quad$ Fasso, op. cit. u bilj. 8, str. $542-543$.

22 Ibid.

23 Grosswald Curran, op. cit. u bilj. 2, str. 157.

24 Bix, B., Radbruch's Formula and Conceptual Analysis, The American Journal of Jurisprudence, vol. 56, 2011., str. 56.

25 Kantorowicz, op. cit. u bilj. 2, str. 13. Vidi o tome: Padjen, I.; Pokrovac, Z.; Opatić, N., Zabrana uskrate pravosuda i uskrate prava: pristup hrvatskim problemima, u: Pokrovac, Z.; Padjen, I. (ur.), Zabrana uskrate pravosuđa i prava: 11. njemačko-hrvatski pravnički simpozij, Split, 27. - 28. travnja 2007. / Justiz- und Rechtsverweigerungsverbot: 11. deutsch-kroatisches Juristensymposium, Split, 27 - 28 April 2007, Pravni fakultet u Splitu, Split, 2010., str. $231-281$.

${ }^{26}$ Lubben, S. J., Chief Justice Traynor's Contract Jurisprudence and the Free Law Dilemma: Nazism, the Judiciary, and California's Contract Law, Southern California Interdisciplinary Law Journal, vol. 7, 1988., str. 86.

27 Ibid.

28 Joerges, op. cit. u bilj. 5, str. 172. Vidi također Lubben, op. cit. u bilj. 26, str. 82. Vidi Gnavius Flavius, The Battle for Legal Science, German Law Journal, vol. 12, br. 11, 2011., str. 2024. 
navođenjem primjera iz njemačke sudske prakse tog vremena u kojima se došlo do apsurdnih rješenja doslovnim tumačenjem zakona. ${ }^{29} \mathrm{U}$ jednom slučaju oporuka je bila proglašena nevažećom zbog striktne primjene odredbe Građanskog zakonika, koja je tražila da potpis oporučitelja bude na kraju dokumenta, a u konkretnom slučaju oporučitelj se potpisao na istoj razini na kojoj se nalazio datum. ${ }^{30}$ Apsurdnost ovog pristupa može se primijetiti i u kaznenopravnim slučajevima. Tako su pojedinci koji su primili ukradeno dobro bili zaštićeni čl. 259. Kaznenog zakona (Strafgesetzbuch, StGB). Naime, sudovi striktnim tumačenjem navedenog članka nisu u početku kažnjavali primatelje ukradenih predmeta ako ono što su zaprimili nije bilo neposredan objekt krađe, nego ono za što je ukradeno bilo zamijenjeno. ${ }^{31}$ Primjerice, ako su zaprimili dijamantni prsten koji je kupljen ukradenim novcem. ${ }^{32}$

Takve "groteskne apsurdnosti" pripadnici pokreta pripisali su pojmovnoj jurisprudenciji i njezinoj nevidljivoj mreži pravila koja mogu odgovoriti na sve probleme znanstveno bez upućivanja na pravu strane vrijednosti. ${ }^{33}$ Pripadnici pokreta težili su zamijeniti formalizam sustavom koji uzima u obzir društvene okolnosti u kojima pravni spor nastaje te načelo pravednosti. ${ }^{34}$ Pravo je neizbježno nepotpuno ${ }^{35}$, a upotreba formalne pravne supsumpcije često neko-

29 Kelly, J. M., A Short History of Western Legal Theory, Oxford University Press, Oxford, 2010., str. 359.

30 Riječ je o odluci Visokog suda Prusije (Kammergericht), koji je odluku utemeljio na članku 2247. Građanskog zakona (izvorna verzija iz 1896.). Foulkes, op. cit. u bilj. 1, str. 372.; Kelly, op. cit. u bilj. 29, str. 359.

31 Foulkes, op. cit. u bilj. 1, str. $372-373$.

32 Ibid.

33 Kelly, op. cit. u bilj. 29, str. 359 - 360.

34 Lubben, op. cit. u bilj. 26, str. 82.

35 Prema Kantorowiczu "nema manje praznina nego riječi”. Kantorowicz, op. cit. u bilj. 2, str. 13.

Kako ističe Bulygin, ne treba zaboraviti da je pojam potpunosti odnosni pojam. Ona nije apsolutna "osobina normativnog sustava nego je umjesto toga odnos između normativnog sustava i vrste radnji (a class of action)”. Također je potrebno razlikovati praznine "u kojima radnja nije regulirana s onima u kojima nije zadovoljavajuće regulirana (u skladu s nekim kriterijem vrednovanja)". Bulygin, E., Essays in legal philosophy, Oxford University Press, Oxford, New York, 2015., str. 133. O pojmu i razlikovanju normativnih, tehničkih i vrijednosnih pravnih praznina vidi Guastini, R., Sintaksa prava, Naklada Breza, Zagreb, 2016., str. 367 - 380.

Prema Bulyginu, Kantorowicz čini pogrešku upotrebljavajući “izraz 'praznina’ radi upućivanja na probleme supsumpcije prouzročene konceptualnom neodredivosti (indeterminacy)". To je, prema Bulgynu, potpuno drugo pitanje. "Proces primjene 
risna. ${ }^{36}$ Inauguraciju pokreta označava predavanje austrijskog pravnika Eugena Ehrlicha iz 1903. pod naslovom Freie Rechtsfindung und Freie Rechtswissenschaft ${ }^{37}$, a pokret dobiva ime, kao što smo istaknuli, 1906. objavom Kantorowiczeva manifesta Borba za pravnu znanost. Riječ je o jednom od najcitiranijih njemačkih djela iz prve polovine 20 . stoljeća. ${ }^{38}$

Naravno, ovoj kritici pravnog pozitivizma treba pristupiti s oprezom. Prisutna su i suprotna mišljenja da u okviru pravnog pozitivizma početkom 20. stoljeća uloga sudaca nije bila čisto mehanička, nego je riječ o hiperbolizaciji koju su stvorili sami pripadnici pokreta slobodnog prava. ${ }^{39}$ Važno je istaknuti da je već tijekom oblikovanja njemačkog Građanskog zakonika zakonodavac uvidio da nova dinamika društvenih odnosa traži rješenja koja nisu bila potrebna ni prisutna u velikim kodifikacijama 19. stoljeća. Zakonik je uvođenjem načela, od kojih je najpoznatije savjesnosti i poštenja (Treu und Glauben), sucima već priznao određenu diskreciju u donošenju odluka. ${ }^{40}$ Načelo savjesnosti i poštenja uneseno je u dva članka BGB-a. Prema članku 242. dužnik se mora ponašati sukladno "zahtjevima načela savjesnosti i poštenja uzimajući u obzir normalnu upotrebu”. ${ }^{41}$ Članak 157. propisuje obvezu ugovornih strana da postupaju sukladno ovom načelu. ${ }^{42}$

opće norme na konkretnu situaciju može uključivati poteškoće koje proizlaze iz semantičkih osobina jezika". Primjerice, otvoreni sadržaj (open texture). Bulygin, op. cit., str. 134. Opsežnu elaboraciju problematike pravnih praznina u Kantorowiza vidi u: Pokrovac, op. cit. u bilj. 1, str. $242-254$.

Hermann Kantorowicz, https://www.uni-kiel.de/grosse-forscher/index.php?nid=kantorowicz\&lang=e (1. kolovoza 2019.).

37 Vidi o tome Lubben, op. cit. u bilj. 26, str. 90; Kelly, op. cit. u bilj. 29, str. 359; Schmidt, K. I., Der "Formalismus-Mythos" im deutschen und amerikanischen Rechtsdenken des frühen 20. Jahrhunderts, Der Staat, vol. 53, 2014., str. 455; Pokrovac, op. cit. u bilj. 1, str. $554-557$.

Hermann Kantorowicz, https://www.uni-kiel.de/grosse-forscher/index.php?nid=kantorowicz\&lang=e (1. kolovoza 2019.).

Autorica parafrazira Ingeborg Maus. Vidi Grosswald Curran, op. cit. u bilj. 2, str. 157. Povijesna istraživanja pokazala su da nikad nije bilo "slijepog formalizma" ili "nekritičkog dogmatizma" protiv kojih su se borili pripadnici pokreta slobodnog prava. Schmidt to naziva primjerom upotrebe argumenta strašila (straw man argument). Riječ o "formalističkom mitu". Vidi Schmidt, op. cit. u bilj. 37, str. 446. Fasso, op. cit. u bilj. 8, str. 556 - 557. Štoviše, kako to ističe Pokrovac, Kantorowicz je među prvima koji ističe da kodifikacije ne umanjuju "potrebu za sudačkim stvaranjem prava". Pokrovac, op. cit. u bilj. 1, str. 267. 
Važno je istaknuti da se donošenjem njemačkog Građanskog zakonika nije odgovorilo na mnoga važna aktualna pitanja, a i sam je Zakonik stvorio nove nejasnoće vezane uz njegovu primjenu. Tako, ističe Katharina Isabel Schmidt, nije odgovorio na pitanje o razgraničenju nadležnosti zakonodavne i sudske vlasti, a među novonastalim pitanjima vezanim uz njegovu primjenu ističu se pitanja sučevih ovlasti u vezi s tumačenjem zakonskih odredaba kada su one u suprotnosti s društvenom stvarnošću te što učiniti kada postoje pravne praznine. ${ }^{43}$ Kantorowicz je ovaj zakonodavni razvoj smatrao nedovoljnim. ${ }^{44}$ Kada se u praksi pojavi "neizbježna pravna praznina", treba se predvidjeti da sudac pod određenim okolnostima ima ovlaštenja zakonodavca kao što je to predvidio članak 1. stavak 2. švicarskog Građanskog zakonika. ${ }^{45}$ Svoje je ideje elaborirao u tri stupnja; novo shvaćanje prava, pravne znanosti i pravosuđa. ${ }^{46} \mathrm{U}$ prvom dijelu članka usredotočit ćemo se na one segmente njegove teorijske misli bez kojih nije moguće odgovoriti na kritike o povezanosti ideja o slobodnom pravu s ponašanjem njemačkih sudaca u nacionalsocijalističkom razdoblju.

\subsection{Slobodno pravo kao prirodno pravo}

Kantorowicz je smatrao da se pojam prava ne može poistovjetiti s pozitivnim državnim pravom. ${ }^{47}$ Ustvrdio je da uz državno pravo postoji slobodno pravo koje nastaje od pravnog mišljenja članova društva, sudskih presuda i pravne znanosti. ${ }^{48}$ U članku koju je objavio 1934. godine Some Rationality about Realism u The Yale Law Journal sažima doktrinu slobodnog prava na sljedeći način:

43 Schmidt, op. cit. u bilj. 6, str. 126.

44 Kelly, op. cit. u bilj. 29, str. 360.

45 Ibid. No, važno je napomenuti da je sudac u takvim slučajevima dužan slijediti postojeću doktrinu i sudsku praksu (čl. 1. stavak 3. švicarskog Građanskog zakonika). Švicarski Građanski zakonik stupio je na snagu 1912., a smatra se ozbiljenjem teorijskih promišljanja Francuza Françoisa Gényja, koji je bio istaknuti predstavnik francuskog antiformalističkog pokreta. Ibid., str. 363. Vidi također Schmidt, op. cit. u bilj. 37, str. 456.

46 Kantorowicz, op. cit. u bilj. 2, str. 9; Kantorowicz Carter, F., Gustav Radbruch and Hermann Kantorowicz: Two Friends and a Book - Reflections on Gnaeus Flavius' Der Kampf um die Rechtswissenschaft (1906), German Law Journal, vol. 7, br. 7, 2006., str. 681.

47 Hart, H. L. A., Reviewed Work: The Definition of Law by Hermann Kantorowicz, A. H. Campbell, A. L. Goodhart, The Philosophical Review, vol. 69, br. 2, 1960., str. 272; vidi također Pokrovac, op. cit. u bilj. 1, str. 204. Kantorowicz, op. cit. u bilj. 2, str. 10.

48 Fasso, op. cit. u bilj. 8, str. 556. 
“Tradicionalni izvori prava, 'formalno' pravo, zakoni i precedenti, imaju praznine koje se moraju popuniti, moraju se popuniti pravom, ako će odluka biti sudska odluka, a to pravo mora imati opći karakter želi li se održati jednakost pred zakonom; građa koja popunjava praznine mora stoga sadržavati pravila, pravna pravila. To je ‘slobodno' pravo u smislu da nije formalno pravo: da nije formalizirano, da je još u stanju tranzicije poput prijedloga zakona, načela politike, poslovnih običaja, neartikuliranih uvjerenja, emocionalnih sklonosti. Mnoge od njih formulirali su sudovi zbog konkretne sudske odluke, postupajući unutar svoje diskrecije, koristeći postupak volje i vrijednosne prosudbe te stoga čine sudski stvoreno pravo. Njihova je valjanost mnogo manja od one formalnog prava, a katkad i nikakva, ali njihova je praktična važnost tim veća jer ondje gdje je formalno pravo jasno i potpuno, nije vjerojatno da će doći do sudskih postupaka". ${ }^{4}$

Slobodno pravo "živi” neovisno od državnog prava, štoviše, ono prethodi državnom pravu. ${ }^{50}$ Prema riječima samog Kantorowicza: "Slobodno pravo je tlo iz kojeg proizlazi državno pravo: gotovo sve zakonodavne ideje prethodno su postojale kao propisi slobodnog prava". ${ }^{51}$

Kad je riječ o izboru izraza za označavanje ove pojave, Kantorowicz se odlučio za izraz "slobodno", što se nije pokazalo najsretnijim izborom. Kantorowicz je upotrijebio sintagmu "slobodno pravo" prema uzoru na slobodno nedogmatsko vjersko mišljenje ${ }^{52}$ : “... naš pokret ... prema analogiji sa slobodnim religioznim, označavat ćemo kao pokret slobodnog prava". ${ }^{53}$

Iz njegove prepiske u vrijeme nastanka Borbe za pravnu znanost s jednim od najvećih njemačkih pravnika 20. stoljeća Gustavom Radbruchom, s kojim je održavao prijateljstvo od 1903. godine kada su se upoznali na seminaru Franza von Liszta u Berlinu, vidljivo je Radbruchovo nastojanje da ga usmjeri na odabir drugog naziva. ${ }^{54}$ Radbruch je na razglednici upućenoj Kantorowiczu 23. srpnja 1905. napisao da smatra izraz "nezakonsko pravo" (außerstaatliches Recht) i dalje primjerenijim od izraza "slobodno pravo" (freies Recht). ${ }^{55}$ No, Kantorowicz nije

49 Kantorowicz, op. cit. u bilj. 2, str. 1241.

50 Fasso, op. cit. u bilj. 8, str. 556.

51 Zadržani su izvorni naglasci iz citiranog teksta. Kantorowicz, op. cit. u bilj. 2, str. 12. Vidi o tome i Pokrovac, op. cit. u bilj. 1, str. 230 - 231.

52 Kelly, op. cit. u bilj. 29, str. 360. O "nesretnosti” odabira naziva slobodno pravo vidi također Pokrovac, op. cit. u bilj. 1, str. 220 - 224.

53 Zadržani su izvorni naglasci iz citiranog teksta. Kantorowicz, op. cit. u bilj. 2, str. 11.

54 Kantorowicz Carter, op. cit. u bilj. 46, str. 657.

55 Ibid., str. 666. 
poslušao Radbrucha jer mu je izraz "slobodno pravo", ističe Frank Kantorowicz Carter, vjerojatno bolje zvučao kao borbeni poklič u manifestu ${ }^{56}$ od izraza "nezakonsko pravo" koji je predložio Radbruch. ${ }^{57}$ Nesporazum koji je proizašao iz tog nespretno odabranog naziva - da suci mogu ignorirati zakonska pravila - o čemu će biti riječi nešto poslije, pratio ga je do kraja karijere. ${ }^{58}$ Kantorowicz je uvidio važnost određenih aspekata prirodnopravnih teorija ${ }^{59}$ te u Borbi $z a$ pravnu znanost upućuje na slobodno pravo kao nov oblik prirodnog prava, kao na "prirodno pravo 20. stoljeća". ${ }^{60}$

“... pri svakom praćenju prirodnog prava sve do njegova posljednjeg utočišta, ideja-vodilja je bila da učenje o prirodnom pravu treba odbaciti jer je impliciralo neko univerzalno pravo, nedeterminirano prostorom i vremenom, posebice ne državom; riječ je o nemogućem. Pri revidiranju te percepcije ... nije se primijetilo ... da je kod prirodnog prava bilo okarakterizirano samo ono što ono nije bilo, jer to, prema pretpostavci, uopće nije moglo biti: naime, uzalud sanjano, nepromjenjivo pravo ... prirodno pravo je bilo pravo koje je imalo pretenzije vrijediti neovisno o državnoj vlasti. Označujući svako takvo pravo kao slobodno pravo, smijemo i prirodno pravo odmah i u prvi mah obilježiti kao posebnu vrstu slobodnog prava". ${ }^{61}$

Schmidt ističe da to nije bilo samo retoričko sredstvo. ${ }^{62}$ Kantorowicz je time odbacio stajalište da država u potpunosti definira pravo. ${ }^{63}$ Vjerovao je da je pojam prava temeljni pojam, a država izvedeni. ${ }^{64}$

Kantorowiczevo prirodno pravo znatno se razlikuje od svojih povijesnih prethodnika. Za razliku od prethodnih teorija prirodnog prava, koje se temelje na božanskoj moralnosti ili razumu, slobodno pravo kao novo prirodno pravo potječe isključivo od ljudskog iskustva. ${ }^{65} \mathrm{U}$ ortodoksnoj teologiji i dogmatskoj pravnoj znanosti imamo dva entiteta koja se nalaze izvan iskustva: Boga i za-

\footnotetext{
56 Ibid.

57 Ibid.

58 Ibid., str. 685; vidi također Kelly, op. cit. u bilj. 29, str. 360.

59 Grosswald Curran, op. cit. u bilj. 2, str. 160.

60 Schmidt, op. cit. u bilj. 6, str. 135.

${ }_{61}$ Zadržani su izvorni naglasci iz citiranog teksta. Kantorowicz, op. cit. u bilj. 2, str. 9. Vidi također Grosswald Curran, op. cit. u bilj. 3, str. $82-83$.

62 Ibid.

${ }^{63}$ Kako ističe Grosswald Curran, to ga odvaja od nacističke teorije prema kojoj je cjelokupno pravo državno pravo. Grosswald Curran, op. cit. u bilj. 3, str. 90.

64 Ibid., str. 84; Kantorowicz, op. cit. u bilj. 2, str. 12.

65 Schmidt, op. cit. u bilj. 6, str. 135.
} 
konodavca, a teorija slobodnog prava stavlja naglasak na ulogu suca ${ }^{66}$, o čemu će biti više riječi u sljedećim poglavljima.

Kantorowicz slijedi pripadnike pozitivističke pravne škole, odbacujući postojanje nepromjenjivih, univerzalnih i vječnih istina koje podupiru pravo. ${ }^{67}$ Predstavnici prirodnog prava su pogriješili, ističe Kantorowicz, prihvaćajući mogućnost postojanja jednog općevažećeg prava, pravo je uvijek "povijesno i pojedinačno čvrsto uvjetovano". 68

\subsection{Novo shvaćanje pravne znanosti kao izvora prava}

Kantorowicz ističe da se odnos pravne znanosti prema zakonu mora u bitnom promijeniti. Budući da zakon ne može zadovoljiti sve pravne potrebe, pravna znanost mu tu treba priskočiti u pomoć. ${ }^{69}$

"Znanost kao izvor prava, taj pojam, s kojim se stara povijesnopravna škola višestruko igrala, mora se napokon shvatiti ozbiljno. Znanost treba pružiti definicije svih pojmova - ne s pomoću 'konstrukcija', nego opskrbljivanjem onim obilježjima koja će propise slobodnog prava staviti na raspolaganje. Ona treba popuniti pravne praznine, ne poricanjem zahtjeva u svim onim slučajevima u kojima ih zakon ne odobrava, nego potvrđivanjem u smjeru koji joj pokazuje slobodno pravo". 70

Pravna znanost time dobiva novu i odlučujuću ulogu. Njezina je zadaća ukloniti "odumrle elemente zakona", a poduprijeti "one koji cvjetaju". ${ }^{71}$ Kao izvor prava, ona nije više samo "spoznavanje poznatog". ${ }^{72}$ Njezina priroda ista je kao i svih ostalih izvora. Poput samog prava, ona mora biti volja. ${ }^{73}$ Time pravna znanost poput ostalih duhovnih znanosti 19. stoljeća stupa u "voluntarističku fazu". ${ }^{74}$ Pravna znanost nije više "verbalna znanost", njezine zadaće nisu iscrpljene tumačenjem utvrđenih riječi, nego je ona "vrijednosna znanost

66 Gnavius Flavius, op. cit. u bilj. 28, str. 2022; Kantorowicz, op. cit. u bilj. 2, str. 38. Vidi također Schmidt, op. cit. u bilj. 6, str. 135.

67 Grosswald Curran, op. cit. u bilj. 3, str. 90.

68 Kantorowicz, op. cit. u bilj. 2, str. 10.

69 Ibid., str. 17; usporedi Gnavius Flavius, op. cit. u bilj. 28, str. 2013.

70 Ibid.

71 Ibid.

72 Ibid.

73 Ibid.

74 Ibid., str. 18. O tome vidi također Pokrovac, op. cit. u bilj. 1, str. 207. 
koja je u službi svrha socijalnog života". ${ }^{75}$ Također treba uvažiti "emocionalne vrijednosti". ${ }^{76}$

\subsection{Uloga sudaca}

Kantorowicz i drugi pripadnici slobodnopravnog pokreta razvijali su pojmove kojima su odbacili dotadašnje poimanje sudske uloge kao mehaničke i manje važne. ${ }^{77}$ Kantorowiczev prikaz vladajuće pravne metodologije je sljedeći:

"Uči se da pravnik može bilo koji pravni slučaj riješiti supsumpcijom pod zakon i da baš zbog toga mora rješavati jedino po njemu. Zakon je - tako je shvaćanje točno označeno - prema tome automat: gore se ubaci slučaj, dolje se izvuče rješenje. Ili je slučaj neposredno riješen u zakonu - tada će rješenje ispasti pri prvom vučenju, ili nije riješen - tada se automat mora nekoliko puta udariti i prodrmati". ${ }^{78}$

No, važno je na početku istaknuti da nije zagovarao ono što su mu brojni kritičari pripisivali, slobodu sudaca da donose odluke contra legem (contra legem bajka). U predavanju Pravna znanost i sociologija, održanom 22. listopada 1910. u Frankfurtu na Majni na Prvom kongresu njemačkih sociologa, Kantorowicz tvrdi:

“... moram računati s mogućnošću da je i u ovu salu prodrla široko rasprostranjena bajka: zastupnici slobodnog prava htjeli su slobodnog suca, tj. osporavali su obveznost zakona, htjeli su našim sucima dopustiti da sude contra legem, i to je bit željenih novina. Nebrojeno smo puta prosvjedovali protiv tog podmetanja i pokušavali ga spriječiti u začetku". ${ }^{79}$

Kantorowicz je tako izričito odbacio mogućnost suđenja contra legem. ${ }^{80} \mathrm{Nes}$ porazum koji je, kako smo vidjeli, u određenom smislu posljedica nespretnog odabira naziva škole 1906. godine. Suđenje prema zakonima (ex lege), ističe Kantorowicz, i ubuduće će ostati dominantno. No, pritom Kantorowicz odbacuje metodologiju tada vladajuće pojmovne jurisprudencije koju još označuje

75 Kantorowicz, op. cit. u bilj. 2, str. 91.

76 Prema Kantorowiczu, pravna znanost treba postati kreativna i antidogmatska. Vidi Schmidt op. cit. u bilj. 37, str. 459; Gnavius Flavius, op. cit. u bilj. 28, str. 2024.

77 Time su slijedili stope nekih važnih prethodnika, primjerice Rudolfa von Iheringa. Grosswald Curran, op. cit. u bilj. 2, str. 157.

78 Kantorowicz, op. cit. u bilj. 2, str. 83. Usporedi Schmidt, op. cit. u bilj. 37, str. 458.

79 Kantorowicz, op. cit. u bilj. 2, str. 88.

80 Ibid., str. 91. 
kao "doslovnu jurisprudenciju" - budući da "ne vodi brigu o svrhama zakona i potrebama života" ${ }^{81}$ Cilj je Pokreta bio modernizirati pravo, težilo se "uzajamnom prožimanju prava i sociologije". ${ }^{82}$ Sociologija je "najplemenitija pomoćna znanost" jurisprudencije. ${ }^{83}$

Najvažnije područje na kojem treba doći do prožimanja prava i sociologije nalazi se u području suđenja sine lege. ${ }^{84}$ Znači, pokret slobodnog prava usredotočen je na područje koje nije pokriveno zakonodavnim aktima, na međuprostor između zakonodavnih akata. ${ }^{85}$

Pripadnici pokreta pribojavali su se da "vladajuća dogma o nepostojanju pravnih praznina" - omogućuje "sucima da potajno unesu u svoje odluke subjektivne vrijednosne prosudbe koje su, zbog konzervativne, birokratske i režimu lojalne prirode imperijalnog njemačkog sudstva" u suprotnosti s "političkim i ideološkim slaganjima slobodnih pravnika" 86 , što dovodi u pitanje pravnu sigurnost. ${ }^{87}$

Opisana obilježja tadašnjeg njemačkog sudstva bila su rezultat Bismarckovih radikalnih reformi iz 1878. godine, kojima se sudska vlast trebala očistiti od liberalnih sudaca - “čija je politička svjesnost potjecala od revolucionarne ere (1848. godine)". 88 Pravno obrazovanje i sudačka obuka znatno su produljeni, a za cijelo to vrijeme kandidat je bio bez ikakvih primanja, dok su troškovi izobrazbe iznosili između 30.000 i 50.000 maraka. ${ }^{89}$ Zbog tih razloga suci su se uglavnom regrutirali iz redova sinova gornje visoke klase, čiji su očevi sami bili suci ili drugi dužnosnici koji su im mogli priuštiti takvu obuku..$^{90}$

Prema stajalištu pokreta, suci su svoje odluke oblikovali retrospektivno, ali su ih predstavljali kao da su već bile sadržane u pravu. Time su ugrožavali

81 Ibid., str. 91. Vidi o tome i Pokrovac, op. cit. u bilj. 1, str. 366; Schmidt, op. cit. u bilj. 37, str. 456.

82 Kelly, op. cit. u bilj. 29, str. 360.

83 Kantorowicz, op. cit. u bilj. 2, str. $91-92$.

84 Ibid., str. 92.

85 Grosswald Curran, op. cit. u bilj. 2, str. 158.

86 Schmidt, op. cit. u bilj. 6, str. 127; Schmidt op. cit. u bilj. 37, str. 456.

87 Schmidt op. cit. u bilj. 37, str. 456.

88 Ott; Buob, op. cit. u bilj. 9, str. 92.

89 "Od tri do četiri godine studiranja do prvog državnog ispita, za kojim je slijedilo trogodišnje ili, uglavnom, četverogodišnje razdoblje u svojstvu sudskog vježbenika (Referendarzeit) prije drugog državnog ispita, za kojim je slijedilo daljnje razdoblje (Assessorenzeit) u trajanju između pet i deset godina”. Ibid., str. 93. 
pravnu sigurnost i predvidljivost. ${ }^{91}$ Kao alternativni pristup predložili su otvoreno prihvaćanje sudskog stvaranja prava, ali isključivo u slučajevima kada je pozitivno pravo nepotpuno, neodređeno ili bi njegova doslovna primjena rezultirala odlukama koje nisu u skladu s "društvenom stvarnošću" ili "sudskim osjećajem pravednosti".$^{92}$ Suci trebaju otvoreno priznati da u praksi posežu za profesionalnom diskrecijom, kao alatom kojem se utječu kad su iscrpljene sve druge mogućnosti. ${ }^{93}$ Kada u konkretnom predmetu postoji pravna praznina, suci to moraju otvoreno priznati te obznaniti čime su se vodili pri donošenju odluke u tom predmetu. ${ }^{94}$ Kako to ističe Katharina Isabel Schmidt, "u teoriji, zastupnici slobodnog prava poštovali su ili vrstu psihološko-sociološkog uvida u stvarne životne procese ili vježbu sudske odgovornosti ograničene odgovarajućom moralnom i pravnom edukacijom kao adekvatnim izvorom normativnosti". ${ }^{95}$

S obzirom na to da suci više nemaju samo mehaničku ulogu, od ključne je važnosti odabir sudaca, kriterij odabira mora biti njihova izvrsnost, i to ne samo u poznavanju pravnih pravila. Godine 1906. u Borbi za pravnu znanost Kantorowicz je tvrdio da su potrebni "suci koji su upoznati kako sa pravnim shvaćanjima vladajućim u narodu, tako i sa životnim činjenicama i rezultatima srodnih znanosti". ${ }^{96}$ Suci trebaju biti "specijalisti činjeničnog stanja, ne opsjenari pravnog propisa". ${ }^{97}$

Kantorowicz je i 1934. godine, godinu dana nakon što je bio prisiljen napustiti Njemačku i uputiti se u Sjedinjene Američke Države, u već spomenutom članku Some Rationalism about Realism pisao da postupak izbora sudaca mora biti visokoselektivan..$^{98}$

“... samo najbolji suci, samo pravnici koji znaju više od prava, koji su temeljito proučavali, ne samo iskusili, stvarni ekonomski i društveni život, njegove učinke i potrebe, sposobni su zamisliti i formulirati odgovarajuća pravila za konkretne slučajeve. Ne smije se prigovoriti da bi to bio zadatak isključivo za sudsku diskreciju. Diskrecija se ne protivi pravilima, kao što se obično kaže; to je intuitivan način pronalaženja pravila: onih 'neartikuliranih glavnih

91 Schmidt, op. cit. u bilj. 6, str. 127; Schmidt, op. cit. u bilj. 37, str. 456.

92 Schmidt, op. cit. u bilj. 6, str. 127.

93 Ibid.

94 Ibid.

95 Ibid.

96 Kantorowicz, op. cit. u bilj. 2, str. $37-38$.

97 Ibid., str. 38.

98 Kantorowicz, op. cit. u bilj. 1, str. 1244. Vidi o tome također Grosswald Curran, op. cit. u bilj. 2, str. 158 . 
premisa', koje moraju biti opće, ako žele biti glavne premise te koje moraju biti pravna pravila ako žele služiti kao glavne premise sudskih odluka". ${ }^{99}$

Kantorowicz je istaknuo da njegova borba, odnosno borba njegovih istomišljenika, nema konstitutivno nego deklaratorno značenje, oni samo deklariraju ono što suci već čine i oduvijek su to činili. ${ }^{100}$ Kantorowicz je tako oblikovao teoriju koja potiče "sudsko vaganje vrijednosti" na nepozitivistički način ${ }^{101}$, koja uvažava svu složenost presuđivanja i "uzajamnu interaktivnu dinamiku između sudske diskrecije i usvojenih zakona". ${ }^{102}$ Kantorowicz je upozoravao na granice pravne logike, ali nije zagovarao popunjavanje zakonskih praznina putem "subjektivnih sudskih osjećaja”. ${ }^{103}$ Kako to ističe Grosswald Curran, Kantorowicz je isticao životno iskustvo, što je bilo u suprotnosti s tradicionalnim kontinentalnim procesom deduktivnog rasuđivanja kojemu je polazište bila apstraktna pravna norma. ${ }^{104}$ Slobodnopravni pokret je promatrao sudsko donošenje odluka kao "dio dinamike između zakonskog prava i mijenjajućih socijalnih potreba". ${ }^{105}$

Vladajuće strogo gledanje na ulogu suca u sudskom postupku pokazuje zašto su se kontinentalnopravni teoretičari tog razdoblja ustručavali predlagati mogućnost da suci preoblikuju ili odbiju primijeniti važeće pravo. Za razliku od toga, u common law sustavima, oduvijek je samorazumljivo da suci razvijaju pravo. ${ }^{106}$

\section{KRAJ POKRETA}

Autori se uglavnom slažu da je pokret došao svojem kraju 1914. godine, neposredno pred izbijanje l. svjetskog rata. ${ }^{107}$ Oni koji su pripadali užem krugu pokreta zbog različitih su razloga prestali aktivno zagovarati ideje koje su

99 Kantorowicz, op. cit. u bilj. 1, str. 1244.

100 Kantorowicz, op. cit. u bilj. 2, str. 8.

101 Grosswald Curran, op. cit. u bilj. 2, str. 158.

102 Ibid., str. 163.

103 Ibid.

104 Ibid.

105 Ibid., str. 166.

106 Bix, op. cit. u bilj. 24, str. 56.

107 Kelly, op. cit. u bilj. 29, str. 359; Schmidt, op. cit. u bilj. 6, str. 125; Schmidt, op cit. u bilj. 37, str. 458; Herget, J. E.; Wallace, S., The German Free Law Movement as the Source of American Legal Realism, Virginia Law Review, vol. 73, br. 2, 1987., str. 417. Vidi o tome i Pokrovac, op. cit. u bilj. 1, str. $554-557$. 
početkom stoljeća borbeno isticali. ${ }^{108}$ Njegovu kraju svakako su pridonijeli i nastanak "institucionalnog nacionalizma, antisemitizma i desnog idealizma". 109 Time je, ističe Schmidt, povijesni trenutak - u kojem su njemački pravnici bili u poziciji da sustavno preoblikuju metodološke temelje prava bez velike pompe nestao. Većina se teoretičara slaže da u njemačkoj pravnoj znanosti 20. stoljeća nije ostavio dublje tragove. ${ }^{110}$ Njemačka pravna znanost i nakon Kantorowicza ostala je u svojem najvećem dijelu pravnopozitivistička. ${ }^{111}$

No, premda je razdoblje u kojem su autori u svojim radovima aktivno zagovarali ideje pokreta završilo neposredno pred izbijanje l. svjetskog rata, završetkom ovog prvog velikog svjetskog sukoba u 20. stoljeću te dolaskom nacista na vlast u Njemačkoj 1933. godine pojavili su se, prema određenim shvaćanjima, prvi važni praktični učinci ovog pokreta koji su ga doveli na zao glas i ponovno učinili predmetom znanstvenog interesa. ${ }^{112}$

\section{RASPRAVE O ULOZI IDEJA POKRETA SLOBODNOG PRAVA U NACISTIČKOJ NJEMAČKOJ}

U ovom dijelu rada usredotočit ćemo se na pitanje koje do današnjih dana zaokuplja pravne teoretičare: jesu li svojim napadom na pravni pozitivizam pripadnici ovog pokreta (neizravno) odgovorni za nacističku pravnu teoriju i praksu. ${ }^{113}$ Njemačka je pravna teorija pokušala objasniti sudsko ponašanje tijekom nacionalsocijalističkog razdoblja u dvije faze. ${ }^{114}$ Prvu fazu obilježio je napad na pravni pozitivizam i njegovo nerazlikovanje "prava kakvo ono jest" i "prava kakvo bi trebalo biti”. ${ }^{115}$ Ova faza nastupila je neposredno nakon završetka 2.

${ }_{108}$ Kantorowicz je za vrijeme l. svjetskog rata bio dobrovoljac, isprva je služio u medicinskoj jedinici, a zatim je bio zadužen za britanske zatvorenike. Poslijeratne godine posvetio je pisanju izvješća za Parlament o uzrocima l. svjetskog rata, koje je naišlo na veliko neodobravanje u njegovoj domovini, jer je krivnju pripisao Austriji i Njemačkoj. Izvješće je objavljeno tek 60-ih godina 20. stoljeća. Herget; Wallace, op. cit. u bilj. 107, str. 417. Vidi također https://www.uni-kiel.de/grosse-forscher/ index.php?nid=kantorowicz\&lang=e.

109 Schmidt, op. cit. u bilj. 6, str. 128; Schmidt, op. cit. u bilj. 37, str. 458.

110 Fasso, op. cit. u bilj. 8, str. 559.

111 Ibid.

112 Herget; Wallace, op. cit. u bilj. 107, str. 418.

113 Grosswald Curran, op. cit. u bilj. 2, str. 158.

114 Dubber, op. cit. u bilj. 1, str. 1807.

115 Ibid. 
svjetskog rata, kada se iz tzv. unutarnjeg egzila vratio bliski Kantorowiczev prijatelj i aktivni suradnik u radu na Borbi za pravnu znanost Gustav Radbruch ${ }^{116}$, koji je od 1945. do 1949. u svojim radovima i predavanjima isticao da postoji pravo izvan pozitivnog prava (übergesetzliches Recht, iznadzakonsko pravo). ${ }^{117}$ Njegovi poslijeratni spisi bili su smjernice pokušajima "ozbiljenja” pravednosti poslije dvanaest godina "zakonskog neprava" i pravne nesigurnosti. ${ }^{118}$ Radbruch u članku Zakonsko nepravo i iznadzakonsko pravo iz 1946. godine, koji se danas smatra jednim od najvažnijih tekstova 20. stoljeća ${ }^{119}$, tvrdi da je vladajući pozitivizam (“zakon je zakon”) učinio “njemački pravnički stalež nemoćnim pred zakonima autokratskog i zločinačkog sadržaja”. ${ }^{120}$

Radbruch je tako pokrenuo njemačku renesansu prirodnog prava ${ }^{121}$, koja je trajala od 1945. do 1960-ih (Naturrechts Renaissance) tijekom kojeg su razdoblja njemački pisci zagovarali nužnost povratka "vječnim” prirodnopravnim načelima. ${ }^{122} \mathrm{U}$ drugoj fazi autori su objašnjenje ponašanja njemačkih sudaca pronašli u njihovim antiformalističkim tendencijama koje su obilježile njihov rad nakon propasti Njemačkog Carstva i osnivanja Weimarske Republike. Mi ćemo se u ovom radu usredotočiti na tu drugu fazu.

Međutim, važno je na ovom mjestu upozoriti na drukčije poimanje pozitivizma u poslijeratnim spisima nego što je to bilo u razdoblju nastanka Kantorowiczeve Borbe za pravnu znanost. Jedan od glavnih problema s optužbama protiv pozitivizma u teoriji i praksi nacističke Njemačke u neuspješnom je definiranju samog koncepta pravnog pozitivizma. ${ }^{123}$ Pravni pozitivizam “je postao pogrdan naziv za različite vrste grijeha”. ${ }^{124}$ Iz tih je razloga često teško ocijeniti u kojoj

116 Ibid. Vidi također Grosswald Curran, op. cit. u bilj. 2, str. 158.

117 Dubber, op. cit. u bilj. 1, str. 1807. Vidi osobito Radbruchove tekstove Pet minuta filozofije prava (1945.) i Zakonsko pravo i iznadzakonsko pravo (1946.). U Hrvatskoj su objavljeni kao dodatak uz: Gustav Radbruch, Filozofija prava, Naklada Breza, Zagreb, 2019.

118 Mertens, T., But was It Law, German Law Journal, vol. 7, br. 2, 2006., str. 193; vidi također Radbruch, op. cit. u bilj. 117, str. 274.

119 Mertens, op. cit. u bilj. 118, str. 191.

120 Radbruch, op. cit. u bilj. 117, str. 272.

${ }^{121}$ Ott; Buob, op. cit. u bilj. 9, str. 91 - 92. Vidi također Winkler, V., Review Essay - Some Realism about Rationalism: Economic Analysis of Law in Germany, German Law Journal, vol. 6, br. 6, 2005., str. 1038.

122 Winkler, op. cit. u bilj. 121, str. 1038.

123 Dubber, op. cit. u bilj. 1, str. 1820.

${ }^{124}$ Hart, H. L. A., Positivism and the Separation of Law and Morals, u: Hart, H. L. A., Essays in Jurisprudence and Philosophy, Oxford University Press, Oxford, 1983., str. 51. Vidi 
mjeri je neka sudska metodologija ili teorija pozitivistička. ${ }^{125}$ Pravni pozitivizam često se miješa s potpuno drugim vrstama tvrdnji, primjerice, kada i kako se pravo mora poštovati, kako se pravne odredbe moraju tumačiti. ${ }^{126}$

Budući da nemamo prostora za potpunu elaboraciju ovog složenog pitanja, poslužit ćemo se istom metodom koju je primijenio Dubber za istraživanje pozitivističkog doprinosa procesu sudskog donošenja odluka u nacističkoj Njemačkoj, zamislit ćemo da se pozitivizam ne odnosi na doslovno tumačenje zakonskih tekstova, nego na odvajanje prava od moralnosti. ${ }^{127}$ Pravni pozitivizam se tako više ne promatra isključivo kao doktrina tumačenja prema kojoj sudac treba upotrebljavati samo pozitivno pravo, nego ponajprije kao teorija o prirodi prava usredotočena na pojmovno razlikovanje prava i morala. ${ }^{128}$ Pravni pozitivizam kao teorija o prirodi prava ${ }^{129}$ nakon završetka 2. svjetskog rata postala je vrlo nepopularna. ${ }^{130}$ Pozitivizam je postao predmet optužbi da je suodgovoran za zlodjela počinjena pod nacističkom vlašću od strane samih sudaca ${ }^{131}$ koje je obvezao, budući da poriče mogućnost bilo kakve izvanpravne ocjene pozitivnog prava ${ }^{132}$, da slijede postojeća pravna pravila neovisno o vlastitim moralnim osjećajima. Pozitivistička metodologija, tvrde kritičari, dopustila je pravnicima da "racionaliziraju" prvotno sebi, a zatim i drugima, tumačenja pravnih pravila koja bi u svakom drugom kontekstu morali označiti "groteskno nepravednim i nemoralnim". ${ }^{133}$

\subsection{Optužbe protiv pokreta slobodnog prava}

Pravni su znanstvenici relativno brzo počeli iznositi argumente protiv poslijeratne osude pravnog pozitivizma kao glavnog krivca za sudske odluke

o tome također Grosswald Curran, op. cit. u bilj. 2, str. 112, bilj. 36.

125 Vidi Grosswald Curran, op. cit. u bilj. 2, str. 112.

${ }^{126}$ Bix, op. cit. u bilj. 24, str. 52.

127 Dubber, op. cit. u bilj. 1, str. 1824. O odnosu Kantorowiczeve teorije sa prijeratnim i poslijeratnim pozitivizmom vidi u ovom broju i članak Maria Krešića, Pojam presudivosti i Kantorowiczev pristup utvrdivanju sadržaja prava.

$128 \mathrm{Na}$ ovome smo zahvalni anonimnomu recenzentu članka.

129 Bix, op. cit. u bilj. 24, str. 52.

130 Sebok, A. J., Misunderstanding Positivism, Michigan Law Review, vol. 93, 1995., str. 2054.

131 Ibid.

132 Dubber, op. cit. u bilj. 1, str. 1826.

133 Ibid. 
donesene za vrijeme nacionalsocijalističke vladavine te su pokušali dokazati da njemački sudski pristup tijekom tog razdoblja nije bio pozitivistički. ${ }^{134}$ Radbruchovo okrivljavanje pravnog pozitivizma neposredno nakon 2. svjetskog rata činilo se na početku uvjerljivim, ali vrlo brzo autori su počeli isticati povijesne činjenice koje govore protiv takvog određenja. ${ }^{135} \mathrm{U}$ toj drugoj fazi, nakon 2. svjetskog rata, u kojoj su autori pokušali objasniti ponašanje sudaca tijekom nacističkog razdoblja, ističe se da je pozitivizam samo poslužio sucima da se naknadno ekskulpiraju od odgovornosti, "ex post operu ruke u pravnoj teoriji”"136, a da se pravi krivac krije u idejama o kreativnom sucu koje su nastale u okviru slobodnopravnog pokreta. Primjerice, Zimmermann tvrdi da je pokret slobodnog prava bio važan izvor nacionalsocijalizma ${ }^{137}$, a Okko Behrends osuđuje "nezreli entuzijazam" predvodnika tog pokreta. ${ }^{138}$

Nije pozitivizam nego antipozitivizam bio dominantna teorija u njemačkoj pravnoj znanosti u tom razdoblju. ${ }^{139}$ Zakonsko pravo koje je bilo na snazi prije Hitlerova dolaska na vlast ostalo je većinom na snazi i u razdoblju od 1933. do $1945 .{ }^{140}$ Suci i ostali dužnosnici nacističke Njemačke jednostavno su se odmaknuli od teksta postojećeg prava kad god su to smatrali prikladnim. ${ }^{141} \mathrm{U}$ vrijeme nacističke vladavine jamstva pravne države nisu uklonjena zakonodavnim putem nego sudskom praksom. Suci su rješavali "kaznenopravne slučajeve s političkom dimenzijom" pozivom na načela nacističkog režima, primjerice, "Führerprinzip", "Geist nacionalsocijalizma", "moralni osjećaj naroda". ${ }^{142}$ Naizgled se čini da su njemački pravni znanstvenici i praktičari tog vremena dosljedno slijedili naputke

134 Vidi o tome Grosswald Curran, op. cit. u bilj. 3, str. 69. Grosswald Curran, među ostalima, upućuje na radove Waltera Otta i Franziske Buob Did Legal Positivism Render German Jurists Defenceless During the Third Reich? (Social \& Legal Studies, vol. 2, br. 1, 1993., str. 91 - 104) te Christiana Joergesa History as Non-History: Points of Divergence and Time Lags between Friedrich Kessler and German Jurisprudence (The American Journal of Comparative Law, vol. 42, br. 1, 1994., str. 163 - 193). Ibid., str. 69, bilj. 11.

135 Ott; Buob, op. cit. u bilj. 9, str. 92.

136 Dubber, op. cit. u bilj. 1, str. 1827.

137 Zimmermann, op. cit. u bilj. 10, str. 239.

138 Behrends, O., Von der Freirechtsschule zum konkreten Ordnungsdenken, u: Dreier, R.; Sellert, W. (eds.), Recht und Justiz im "Dritten Reich", Suhrkamp, Frankfurt am Main, 1989., str. 34 et seq., 27 et seq., 77, navedeno prema Joerges, op. cit. u bilj. 5, str. 187.

139 Winkler, op. cit. u bilj. 121, str. 1040.

140 Paulson, L. S., Lon L. Fuller, Gustav Radbruch, and the "Positivist Theses", Law and Philosophy, vol. 13, br. 3, 1994., str. 331.

141 Ibid., str. 332.

142 Ibid. 
kritičara pravnog formalizma, "odstupali su od pravnih pravila i rješavali slučajeve pozivom na tzv. moralne osjećaje ljudi (gesundes Volksempfinden)", odnosno tumačili su pravna pravila u cilju ostvarenja "društveno poželjnih ciljeva". ${ }^{43}$ Uzrok pravnom teroru nije bila "nekritička primjena prava donesenog od strane zločinačkog zakonodavca”, nego spremnost pravnika da oblikuju pojmove tako da služe "zločinačkim svrhama". ${ }^{144}$

\subsubsection{Weimarska Republika}

Neki autori ističu da je zakonski pozitivizam (Gesetzespositivismus) prestao biti vodeća doktrina već tijekom trajanja Weimarske Republike. ${ }^{145} \mathrm{O}$ tome postoje različita mišljenja. Pravni pozitivizam temelji se na stabilnosti političke situacije i na jamstvu da će zakonodavac uvijek pronaći "ispravno" rješenje. ${ }^{146} \mathrm{U}$ Njemačkoj to je povjerenje počelo slabiti jačanjem parlamenta krajem Carstva, a potpuno je izgubljeno s Prvim svjetskim ratom. ${ }^{147}$

Weimarska Republika bila je kratkotrajna državna tvorevina koju s pravnog gledišta možemo ocijeniti vrlo dinamičnom. ${ }^{148} \mathrm{U}$ ono vrijeme velikih previranja socijalno i ekonomsko zakonodavstvo zašlo je u dotad neupitno domenu privatnog prava. ${ }^{149}$ "Klasični formalistički pravni pristup" nije bio u stanju prilagoditi institucije privatnog prava novoj stvarnosti. ${ }^{150}$ U vrijeme Weimarske Republike njemački suci su u praksi svojim djelovanjem i sukobom sa zakonodavnom vlašću naveli neke teoretičare na zaključak da su slijedili ideje pokreta slobodnog prava. ${ }^{151}$ Vrhovni sud (Reichsgericht) sudsku nelojalnost prema demokratskim institucijama najavio je u studenom 1923. godine u iznimno bitnoj odluci u slučaju revalorizacije njemačke marke (Reichsmark). ${ }^{152}$

\footnotetext{
143 Somek, A., From Kennedy to Balkin: Introducing Critical Legal Studies from a Continental Perspective, University of Kansas Law Review, vol. 42, 1994., str. 763.

144 Mertens, op. cit. u bilj. 118, str. 196.

145 Ott; Buob, op. cit. u bilj. 9, str. 101.

146 Ibid., str. 96.

147 Ibid.

148 Joerges, op. cit. u bilj. 5, str. 173.

149 Ibid.

150 Ibid.

151 Ibid.

152 Joerges, op. cit. u bilj. 5, str. 173; Ott; Buob, op. cit. u bilj. 9, str. 96.
} 
Tijekom prvih godina Weimarske Republike sudstvo je zauzelo kritički stav prema zakonskom pravu. ${ }^{153}$ Zbog hiperinflacije načelo monetarnog nominalizma ${ }^{154}$ "Marka je marka", koje je dopuštalo da zlatni dugovi izraženi u markama budu ispunjeni s pomoću papirnatih novčanica u optjecaju, dovelo je vjerovnike u neravnopravan položaj. ${ }^{155}$ Vrhovni sud napustio je to načelo u odluci od 28. studenog 1923., primjenjujući načelo savjesnosti i poštenja iz članka 242. njemačkog Građanskog zakonika. ${ }^{156}$ Vrhovni sud otišao je i korak dalje te ovlastio suce da ponovno procjenjuju hipotekarne dugove u skladu s načelom savjesnosti i poštenja. ${ }^{157}$ Zakonske odredbe o tečaju, prema tumačenju Vrhovnog suda, treba zanemariti ako nisu sukladne s načelom savjesnosti i poštenja. ${ }^{158}$ Suci su time dobili ovlast donijeti političku odluku, tj. odrediti novi tečaj. ${ }^{159} \mathrm{Na}$ samu najavu da će vlada pokušati riješiti problem drukčije od načina na koji je to učinio Vrhovni sud, Udruga sudaca uložila je službeni prosvjed vladi. ${ }^{160}$ Ta je odluka otvorila niz pitanja. Jesu li time njemački suci pokazali nelojalnost prema demokratskim institucijama Weimarske Republike? ${ }^{161}$ Je li suce na taj korak inspirirao pokret slobodnog prava? Zašto nisu poštovali legitimitet demokratski izabranog zakonodavca i slijedili formalistički pravni pristup? ${ }^{162}$ Čak i u nekim hrvatskim radovima mogu se pronaći teze da je sudska kreativnost koju su pokazali njemački pravnici dvadesetih godina prošlog stoljeća predstavljala uvod "za napuštanje pravnoga sustava i uvođenja nove, 'nacionalne' pravne ideologije”. ${ }^{163}$

\subsubsection{Zakonodavstvo i sudska praksa od 1933. do 1945.}

Tijekom nacionalističkog razdoblja suci su bili upravo poticani da se upuste u slobodno tumačenje "nekristaliziranih pojmova" radi pogodovanja novoj

153 Ott; Buob, op. cit. u bilj. 9, str. 96.

154 Osrečak, op. cit. u bilj. 41, str. 59.

155 Ott; Buob, op. cit. u bilj. 9, str. 96.

156 Ibid.

157 Ibid.

158 Osrečak, op. cit. u bilj. 41, str. 59.

159 Ott; Buob, op. cit. u bilj. 9, str. 96 - 97.

160 Ibid., str. 97.

161 Joerges, op. cit. u bilj. 5, str. 173.

162 Ibid.

163 Osrečak, op. cit. u bilj. 41, str. 59. 
"moralnosti". ${ }^{164}$ Prema Hergetu i Walleceu time je pojam slobodnog prava konačno postao sredstvo totalitarnih režima. ${ }^{165}$ Velik se broj autora slaže da je nacionalsocijalistička pravna misao bila "dijametralno suprotna pozitivističkom mišljenju". ${ }^{166}$ Tako se navode primjeri istaknutih pripadnika nacističke teorije prava poput Carla Schmitta koji su izričito odbacili normativne temelje prava. ${ }^{167}$ Carl Schmitt u Nationalsozialismus und Völkerrecht, objavljenom 1934. godine, određuje da je nacionalsocijalistički pravni poredak odvojen od "apstraktno-normativnog". ${ }^{168}$ Schmitt je tražio "pravnu analizu u okviru konkretnih pojmova" koji su neovisni o zakonskim pravnim normama. ${ }^{169}$

Führerprinzip nacističke pravne teorije određuje sveukupno pravo kao državno pravo. ${ }^{170}$ Pravo potječe od države koju utjelovljuje Führer. No, Führerprinzip nije bila volja Adolfa Hitlera, nego načelo koje "naređuje sucima da odlučuju o slučajevima kao da je Führer proglasio svoje mišljenje o relevantnim pravnim pitanjima, neovisno o tome je li to zaista napravio". ${ }^{171}$ To podsjeća na članak 1. stavak 2. švicarskog Građanskog zakonika. ${ }^{172}$

Prema Grosswald Curran, problem u objašnjavanju njemačke pravne teorije u ovom razdoblju predstavlja velika razlika između teorije i ondašnje prakse. To se može, ističe autorica, dobro vidjeti na primjeru uloge Volka, kojemu je u pravnoj teoriji pripisivana uzvišena uloga koja upućuje na "novu konceptualizaciju demokracije". ${ }^{173}$ No, problem je u tome što u praksi narod uopće nije imao političko pravo glasa. ${ }^{174}$

Za vrijeme nacionalsocijalističke vladavine njemački Građanski zakonik nije bio formalno ukinut. ${ }^{175}$ Njemački sudovi su "nacificirali" zakone iz vremena prije

164 Herget; Wallace, op. cit. u bilj. 107, str. 418.

165 Ibid., str. 419. Vidi kritiku njihova stajališta kod Grosswald Curran, op. cit. u bilj. 3, str. 87.

166 Ott; Buob, op. cit. u bilj. 9, str. 101.

167 Kako ističe Grosswald Curran, to ih jasno odvaja od Kantorowicza koji je pravo vidio kao normativno. Grosswald Curran, op. cit. u bilj. 3, str. 89.

168 Ibid., str. 89.

169 Dubber, op. cit. u bilj. 1, str. 1819.

170 Grosswald Curran, op. cit. u bilj. 3, str. 80.

171 Ibid., str. 89. Grosswald Curran u ovom dijelu parafrazira profesora Whitmana, prema prepisci koju je vodila s njim od 26. lipnja 2000. Ibid., str. 89, bilj. 65.

172 Ibid., str. 80.

173 Ibid., str. 81.

174 Ibid., str. 82.

175 Grosswald Curran, op. cit. u bilj. 2, str. 170. 
dolaska na vlast upotrebom općih načela (Generalklauseln) kao što su to činili u vrijeme Weimarske Republike. ${ }^{176}$ Time su Židovima uskratili njihova temeljna ljudska prava. ${ }^{177}$ Njemački suci su, primjerice, upotrebom analogije izjednačili Židove s mrtvima tako da se "pojmovi jednakosti i univerzalnosti" vezani uz pravnu sposobnost (Rechtsfähigkeit) mogu i dalje formalno poštovati. ${ }^{178}$ Budući da se njemački Građanski zakonik odnosio samo na žive, time je otklonjena potreba za njegovim mijenjanjem. Opća načela o poslovnom moralu (gute Sitten $)^{179}$ i savjesnosti i poštenju tumačili su tako da su ih strane koje su Židovi samom tom činjenicom prekršile. ${ }^{180}$

Propisi koji su doneseni u ovom razdoblju stavili su sucima na raspolaganje mogućnost zloupotrebe širokih općih načela te drugih pravnih sredstava poput analogije. ${ }^{181}$ Kako to ističu Walter Ott i Franziska Buob:

"Najprominentnija obilježja novih pravnih izraza kao što su völkisches Gedankengut, Gemeinschaft, Rasse, Blut und Boden jesu činjenica da nisu imali praktičnu upotrebu u postupku donošenja odluka. U kombinaciji s Führerprincipom, tj. trajnom mogućnosti upletanja od strane drugih tijela u izvornu sudsku domenu, dopustili su političkom vodstvu da instrumentalizira sudstvo na volju, upotrebom izraza Volksnahe". ${ }^{182}$

U kaznenopravnom području sudska praksa je ekstenzivnim tumačenjem proširila određenja kaznenih djela te su određivane oštrije kazne od propisanih. ${ }^{183}$ Mjerodavni standardi za to su bili najvećim djelom sadržani u "dekretima, preporukama i prijedlozima od strane sudske uprave". ${ }^{184}$ Kazneno pravo tako je doživjelo bitne preinake dekretom od 28. lipnja 1935. Načelo nulla poena sine lege, koje se nalazilo u članku 2. njemačkog Kaznenog zakona iz 1871., tumačilo se u Carskoj Njemačkoj tako da uključuje zabranu retroaktivnog djelovanja zakona i primjenu analogije. ${ }^{185}$ Izmjenom njemačkog Kaznenog zakona od 28. lipnja 1935. novi članak 2. glasio je:

176 Ibid., str. 171.

177 Ibid., str. 173.

178 Ibid., str. 170.

179 O tome vidi Zubović, A., Primjena trgovačkih običaja, Zbornik Pravnog fakulteta Sveučilišta u Rijeci, vol. 27, br. 1, 2006., str. 335.

180 Grosswald Curran, op. cit. u bilj. 2, str. 173.

181 Ibid.

182 Ott; Buob, op. cit. u bilj. 9, str. 94.

183 Ibid., str. 100.

184 Ibid.

185 Paulson, op. cit. u bilj. 140, str. 332. 
"Kažnjena će biti svaka osoba koja počini čin od strane prava proglašen kažnjivim ili koja u svjetlu temeljne svrhe kaznenog zakona, i u sklada sa zdravim narodnim osjećajem (gesundes Volksempfinden) zaslužuje biti kažnjena". ${ }^{186}$

Izmjenama od 28. lipnja 1935. sucima je dopušteno da odlučuju prema ana$\operatorname{logiji.}{ }^{187}$ Ako je u konkretnom slučaju sudac smatrao da zakonski predviđena kazna nije dovoljna, mogao je analogijom počinjeno kazneno djelo usporediti s težim kaznenim djelom te počinitelju izreći strožu kaznu. ${ }^{188}$ Čak i u slučaju da pojedinac određenim činom nije kršio nijedan zakonski propis, sudac ga je mogao upotrebom analogije proglasiti zabranjenim i pojedinca osuditi. ${ }^{189}$ Iz rečenog jasno je da su posljedice za pravnu sigurnost pojedinca bile drastične, nitko nije mogao biti siguran je li njegovo ponašanje nezakonito te koja bi kazna mogla uslijediti. ${ }^{190}$ Isti je dekret sadržavao i odredbu kojem je ovlastio Vrhovni sud Reicha da ne poštuje vlastitu praksu. ${ }^{191}$ Iz svega rečenog proizlazi da je, kako to ističe Kelly, "pod nacionalsocijalističkim režimom ideja odstupanja od strogog pravnog teksta i umjesto toga gledanja prema pravnim vrijednostima (subjektivnim i nepredvidljivima) poput duha prava" imala strašne posljedice. ${ }^{192}$ Svemu

186 Naglasci u tekstu su izvorni. Kelly, op. cit. u bilj. 29, str. 360 - 361.

Kelly radi objašnjenja ove odredbe upućuje na Komentar Schafera i Dohnanyija (objavljen 1936. godine) na novo njemačko zakonodavstvo u razdoblju od 1931. do 1935. Ideja materijalne pravednosti zamjenjuje formalnu te se daje podrška primjeni analogije. Die Strafgesetze der Jahr 1931 bis 1935, 1936., str. 184 - 185, navedeno prema ibid., str. 361.

187 Sfekas, S. J., A Court Pure and Unsullied: Justice in the Justice Trial at Nuremberg, University of Baltimore Law Review, vol. 46, br. 3, 2017., str. 463.

188 Ibid., str. $463-464$.

189 Ibid., str. 464.

190 Ibid.

191 Sfekas, S. J. The Enabler, The True Believer, The Fanatic: German Justice in The Third Reich, The Journal Jurisprudence, vol. 26, 2015., str. 200.

Tužitelja je ovlastio, ako je određenu kaznu smatrao nedovoljno strogom, na podnošenje zahtjeva Ministarstvu pravosuđa za ukidanjem odluke nižeg suda. Ministarstvo pravosuđa moglo je poništiti propisanu kaznu i odrediti strožu. Tužitelju je na raspolaganju stajalo još i jedno izvanredno sredstvo kojim je mogao zatražiti ukidanje oslobađajuće i donošenje osuđujuće presude.

The Extracts from the Law of 28 June 1935 which amended the Criminal (Penal) Code Trials of War Criminals Before the Nuernberg Military Tribunals Under Control Council Law No. 10 (1951) [Justice Transcript], str. 176 - 178, navedeno prema Sfekas, op. cit. u bilj. 187, str. 463 - 464. Vidi također Sfekas, op. cit. u bilj. 191, str. 200.

192 Kelly, op. cit. u bilj. 29, str. 360. 
rečenom suci su se mogli oduprijeti s pravnopozitivističkog gledišta. ${ }^{193}$ Kao i aktivnosti vezane uz provođenja programa eutanazije ("negativne eugenike") nad njemačkim stanovništvom i zločini u koncentracijskim logorima vršeni su bez jasnog zakonskog temelja. ${ }^{194}$

Suđenje pravnicima u Nürnbergu bio je prvi pokušaj dovođenja u pitanje postavke o nedužnosti njemačkog pravosuđa. ${ }^{195}$ United States of America v. Alstötter et al., treće iz niza tzv. nürnberških suđenja, postalo je poznato kao "Sudski proces" (The Justice Trial) jer su šesnaest optuženika bili suci, tužitelji te dužnosnici Ministarstva pravosuđa. ${ }^{196}$ Ono je otkrilo važnost pravne struke za održavanje stabilnosti nacionalsocijalističkog režima. ${ }^{197}$ Osobito zabrinjavajuća jest činjenica da je nacionalsocijalistički režim trajao samo dvanaest godina, što znači da je najveći dio pripadnika pravne profesije bio educiran prije stupanja nacista na vlast. ${ }^{198}$

Groswald Curran ima drukčije viđenje njemačke sudske prakse u ovom razdoblju. Jasno ističe da se pravna metodologija ne može smatrati odgovornom za ponašanje sudaca. Autorica usporedbom prakse francuskih i njemačkih sudaca za vrijeme nacionalsocijalističke vladavine, od kojih su prvi bili strogi formalisti, a drugi antiformalisti, dolazi do zaključka da su i jedni i drugi došli za vrijeme nacionalsocijalističke vladavine do istih tragičnih rezultata, premda su slijedili različitu metodologiju. Za razliku od njemačkih sudaca koji su još za Weimarske Republike širokom upotrebom pravnih načela oblikovali metodologiju koju će nastaviti primjenjivati dolaskom nacista na vlast, francuski su sudovi u vezi s tim bili suzdržani. ${ }^{199}$ Francuski sudovi tijekom 20-ih godina 20. stoljeća odbili su primjenjivati antiformalističke metode, tj. široko tumačiti njihova opća načela (principes généraux), čak i pod cijenu da ugovori postanu nepravedni prema jednoj od stranaka. Taj formalistički pristup francuski sudovi slijedit će i tijekom višijevskog razdoblja. ${ }^{200}$ Grosswald Curran misli da je najvažnije istaknuti da se u sudskoj metodologiji ne nalazi uzrok "nepravde ili sudske nečovječnosti". ${ }^{201}$

193 Ott; Buob, op. cit. u bilj. 9, str. 101.

194 Ibid.

195 Dubber, op. cit. u bilj. 1, str. 1815.

196 “The Justice Case” 3 T.W.C. 1 (1948), 6 L.R.T.W.C. 1 (1948), 14 Ann. Dig. 278 (1948), navedeno prema Sfekas, op. cit. u bilj. 187, str. 459.

197 Broj političkih zatvorenika koje su osudili civilni sudovi popeo se sredinom 1930-ih na 23.000. Sfekas, op. cit. u bilj. 187, str. 457.

198 Ibid., str. 458.

199 Grosswald Curran, op. cit. u bilj. 2, str. 171.

200 Ibid.

201 Grosswald Curran, op. cit. u bilj. 3, str. 90. 
"Moje osnovno gledište jest da oslobađanje od krivnje može biti prošireno na oslobađanje od krivnje pravne metodologije općenito. Dok sudska metodologija nije u potpunosti nepovezana s materijalnim rezultatom, sama po sebi nije bila primarna snaga u određivanju sudskog razrješavanja slučajeva. Dvojna posljedica je sljedeća: dok metodologija nije odgovorna za nepravdu, zbog istog razloga metodološka reforma ne može obećati da će ponuditi uvjerljivo rješenje problema sudske nepravde". ${ }^{202}$

Schmidt također ističe kako je više puta dokazano da različite pravne metode mogu dovesti do sličnih rezultata. ${ }^{203}$ Metode koje promiču napredne socijalne ciljeve ne moraju biti antiformalističke i obratno. ${ }^{204}$ Prema Grosswald Curran, u slučaju okrivljavanja metodologije za nepravdu, moramo pronaći pravu metodologiju koja bi bila rješenje. To smatra prevelikim izazovom. ${ }^{205}$

Grosswald Curran odbacuje optužbe usmjerene protiv Kantorowicza i pokreta slobodnog prava. Odbacuje analogiju između slobodnog prava i sudskih odluka u nacističkom razdoblju njemačke povijesti zato što ne uzima u obzir duboku neusklađenost koja postoji između njih. ${ }^{206}$ Grosswald Curran se osobito osvrće na dva prominentna obilježja prava u tom razdoblju: odbacivanje koncepta prava kao normativnog i poistovjećivanje sveg prava s državnim pravom. Nigdje u Kantorowiczevu opusu, ističe Grosswald Curran, ne nalazi se odbacivanje prava kao normativnog, od Borbe za pravnu znanost do Definicije prava. ${ }^{207} \mathrm{U}$ posmrtno objavljenoj knjizi Definicija prava nalazi se Kantorowiczeva definicija prava kao "sustava pravila" (a body of rules) koja uređuju "vanjsko ponašanje" subjekata i smatraju se presudivima. ${ }^{208}$ Kantorowiczeva koncepcija slobodnog prava kao nove vrsta prirodnog prava očito se ne može poistovjetiti s državnim pravom.

202 Ibid., str. 69.

203 Schmidt, op. cit. u bilj. 37, str. 452.

204 Ibid.

205 Grosswald Curran, op. cit. u bilj. 3, str. 90.

206 Ibid., str. 87.

207 Ibid., str. 89.

208 Prema Kantorowiczu pravo je "sustav pravila koja propisuju vanjsko ponašanje i smatraju se presudivim (justiciable)". Kantorowicz, H., Definition of Law, Campbell, A. H. (ed.), Octagon Books, New York, 1980., str. 21. Na tu činjenicu upućuje i Grosswald Curran, op. cit. u bilj. 3, str. 89.

Pri prijevodu definicije na hrvatski od koristi nam je bio članak Krešić, M., Primjena Kantorowiczeve i Hartove defincije prava na međunarodno pravo, Pravni vjesnik, vol. 29, br. 3-4, 2013., str. 120. Prema Krešićevu prijevodu Kantorowitzeve definicije prava ono je "cjelina društvenih pravila koja propisuju vanjsko ponašanje i koja se smatraju presudiva”. 
Ovo Kantorowiczevo uvjerenje, prema Grosswald Curran, stoji u "nepomirljivom sukobu s nacističkom pravnom teorijom o Führerprinzip". ${ }^{209}$

S druge strane, Walter Ott i Franziska Buob također odbacuju tvrdnju da je metodologija, osobito pravni pozitivizam, imao ulogu u svemu tome te smatraju da se pravi razlog ponašanja njemačkih sudaca ponajprije može “... objasniti njihovim autoritativnim načinom razmišljanja od Bismarckovih reformi sudstva i njihovim antidemokratskim i antiliberalnim gledištima, povezanima s nezamislivom intervencijom političkog vodstva u sudsku domenu". ${ }^{210}$

Povijesna istraživanja pokazuju da je većina njemačkih pravnika prije 1933. bila neprijateljski raspoložena prema Weimarskoj Republici. ${ }^{211}$ Godinu dana od Hitlerova imenovanja za kancelara 30. siječnja 1933. svi njemački suci postali su članovi Udruge njemačkih nacionalsocijalističkih pravnika. ${ }^{212}$ Kako ističe Augusto Zimmermann, nije iznenađujuće da su ti suci našli razloge za oduzimanje prava Židovima čak i bez izričite zakonske podloge. ${ }^{213}$

Kaufmann napominje da se u praksi tadašnjih sudova nalazi “najveća perverzija pozitivizma”. Prevladavao je dvosmjerni pragmatizam: "ako se netko bavio "predrevolucionarnim pravom", tada krutost pozitivizma nije prevladala; ako se netko bavio "nacionalsocijalističkim pravom", tada ga se sudac trebao pridržavati, čak i kada su zakoni bili očito nepravedni. Bitka između sukobljenih koncepata tako je ostala neodlučna, nije postojala nacionalsocijalistička filozofija prava, ni pozitivistička ni iznadpozitivistička". ${ }^{214}$

\section{ZAKLJUČAK}

U razdoblju nakon 2. svjetskog rata pravni su znanstvenici pokušali objasniti ponašanje njemačkih sudaca tijekom nacionalsocijalističke vladavine. Kako su suci, u pravilu obrazovani prije 1933. godine, znači u jednom zapadnoeuropskom pravnom sustavu, završili na optuženičkim klupama u Nürnbergu? Radbruch 1946. godine okrivljuje pravni pozitivizam kao tadašnju vladajuću doktrinu u Njemačkoj za takav razvoj događaja. No, vrlo brzo pojavljuju se

209 Grosswald Curran, op. cit. u bilj. 3, str. 80.

210 Ott; Buob, op. cit. u bilj. 9, str. 101 - 102.

211 Zimmermann, op. cit. u bilj. 10, str. $233-234$.

212 Ott; Buob, op. cit. u bilj. 9, str. 94; Zimmermann, op. cit. u bilj. 10, str. $233-234$.

213 Zimmermann, op. cit. u bilj. 10, str. 234.

214 Kaufmann, A., National Socialism and German Jurisprudence from 1933-1945, Cardozo Law Review, vol. 9, 1988., str. 1645. 
mišljenja da je riječ o iskrivljivanju povijesti te neuzimanju u obzir "sustavnog antipozitivizma u nacionalsocijalističkoj pravnoj misli". ${ }^{215}$ Antiformalizam je tako zamijenio pozitivistički formalizam kao odgovorni krivac za zločine koje su počinili pripadnici pravosudne profesije. ${ }^{216}$ Kritičari su stavili Kantorowicza i ostale pripadnike pokreta slobodnog prava u isti kontekst optužbi s nacističkim pravnim teoretičarima u pogledu nemoći njemačkih pravnika u tom razdoblju. ${ }^{217}$ Optužbe su došle unatoč tome što su Kantorowicz i ostali pripadnici pokreta neupitno zagovarali demokratske ideale. ${ }^{218}$ Kantorowiczeva pravna misao je liberalna. ${ }^{219} \mathrm{U}$ Borbi za pravnu znanost uzore pronalazi u rimskom pravu u razdoblju Pax Romana i britanskoj pravnoj tradiciji, a koncept prava koji kritizira u Bizantu i "centraliziranoj birokratskoj državi modernog apsolutizma". ${ }^{20}$ Ovdje bi se moglo dodati i bilo kojeg oblika totalitarizma. ${ }^{221}$ Kako to ističe Schmidt, suprotno reputaciji koju su imali, pripadnici pokreta slobodnog prava visoko su cijenili načela pravne sigurnosti i predvidljivost. Zakonodavna funkcija suca bila je rezervirana samo za slučajeve u kojima postojeće pravo nije nudilo zadovoljavajući odgovor, bilo zbog toga što je bilo nepotpuno, nejasno ili bi njegova striktna primjena dovela do apsurdnih i grotesknih rezultata. ${ }^{222}$

Kantorowicz je tražio napuštanje postojećeg "umjetnog i nepoštenog sustava" ${ }^{223}$ te ostvarenje pravnih rezultata u skladu sa stvarnošću. ${ }^{224}$ Zagovarao je ideju "suca filozofa", oslobođenog od strogih ograničenja profesionalnih dogmi, koji bi pomoću "svoje slobodne volje" trebao ostvariti "neku vrstu moderne pravednosti" 225 - "ta vrsta pravednosti nije ni apsolutna ni univerzalna, nego ... relativna i odnosna" te proizlazi iz sukladnosti sa stvarnošću koja postaje vidljiva uz pomoć društvenih znanosti. ${ }^{26}$

215 Joerges, op. cit. u bilj. 5, str. 185.

216 Mertens, op. cit. u bilj. 118, str. 196.

${ }^{217}$ Schmidt, op. cit. u bilj. 6, str. 135.

218 Ibid.

219 Auer, M., Der Kampf um die Wissenschaftlichkeit der Rechtswissenschaft - Zum 75. Todestag von Kantorowicz, Zeitschrift für europäisches Privatrecht, br. 4, 2015., str. 782, 798.

${ }^{220}$ Gnavius Flavius, op. cit. u bilj. 28, str. 2006. Vidi također Auer, op. cit. u bilj. 219, str. 782.

${ }^{221}$ Auer, op. cit. u bilj. 219, str. 782.

${ }^{222}$ Schmidt, op. cit. u bilj. 6, str. 127.

${ }^{223}$ Gnavius Flavius, op. cit. u bilj. 28, str. 2022.

${ }^{224}$ Schmidt, op. cit. u bilj. 6, str. 135. Vidi Kantorowicz, op. cit. u bilj. 2, str. 37 - 39.

${ }^{225}$ Schmidt, op. cit. u bilj. 6, str. 134; Schmidt, op. cit. u bilj. 37, str. 466.

226 Schmidt, op. cit. u bilj. 6, str. 134. 
Naglasak je pritom bio na sudskoj nezavisnosti koja mora biti osigurana na način da napredak suca ne smije ovisiti o "političkom moćniku”. ${ }^{227}$ Najviši cilj prava je pravednost: "Samo tamo gdje razlupan kamen malog broja paragrafa, gdje obilje slobodnog prava pruža mogućnost da se svakom da primjereno reguliranje, samo tamo gdje je sloboda - tu je i pravednost". ${ }^{228}$

Premda se u radu nismo upustili u detaljnu elaboraciju i optužbi protiv pozitivizma, one su također upitne. U trenutku kada su nacionalsocijalisti došli na vlast u Njemačkoj 1933. godine, pozitivizam je, unatoč oprečnim mišljenjima, bio vladajuća pravna teorija. No njemačka jurisprudencija weimarskog razdoblja nikako se ne može jednostavno opisati kao pozitivistička. Kao što je to primijetio Dubber, pravni pozitivizam nije bio jedini, ali je i dalje bio glavni akter na sceni. ${ }^{229}$ Važno je u vezi s tim i Kaufmannovo opažanje: "Nacionalsocijalizam nije stvorio vlastitu filozofiju ni pravnu znanost obvezanu na neku filozofsku tradiciju. Nacionalsocijalizam je bio u potpunosti pragmatičan, sastavljajući iz povijesti ona uvjerenja koja su služila njegovoj svrsi". ${ }^{230}$

Kod ocjene utjecaja pozitivizma u Njemačkoj ovog razdoblja u obzir treba uzeti da u pravnoj literaturi postoje različite vrste pravnog pozitivizma - pozitivizam pojmovne jurisprudencije, zakonski pozitivizam, pozitivizam kao odvajanje prava od morala, što su neki od najvažnijih oblika. ${ }^{231} \mathrm{U}$ pokušajima objašnjenja obilježja sudskog ponašanja za vrijeme nacionalsocijalizma, teorija pozitivizma koja se zasniva na odvajanju prava od morala čini se najuvjerljivijom. ${ }^{232}$ Kako ističe Dubber, u ideologiji tog vremena ovoj distinkciji nije bilo mjesta: "moralnost nije imala značenje izvan političkog konteksta, i pravo i politika imali su zajedničke temelje". ${ }^{233}$ Pitanje je li pozitivizam oblikovao nacističku pravnu teoriju je isto tako odvojeno od toga je li se njegova snaga pokazala u pravnoj praksi njemačkih sudova. ${ }^{234}$

${ }^{227}$ Kantorowicz, op. cit. u bili. 2, str. 39.

228 Izvorni naglasci u tekstu su zadržani. Kantorowicz, op. cit. u bilj. 2, str. 39.

229 Dubber, op. cit. u bilj. 1, str. 1819.

230 Kaufmann, op. cit. u bilj. 214, str. 1630. Vidi o tome i Grosswald Curran, op. cit. u bilj. 3, str. 88.

231 Paulson, S. L., On the Background and Significance of Gustav Radbruch's Post-War Papers, Oxford Journal of Legal Studies, vol. 26, br. 1, 2006., str. 38, bilj. 133.

232 Dubber, op. cit. u bilj. 1, str. 1822.

233 Ibid., str. 1822.

234 Robert Cover rekao je da je "sudski pozitivizam" (judicial positivism) a ne "pravnoznanstveni pozitivizam" (jurisprudential positivism) bio dominantan između 1933. i 1945. Cover, R. M., Justice Accused: Antislavery and the Judicial Process, Yale University Press, New Haven, Conn., 1975., str. 8, navedeno prema Dubber, op. cit. u bilj. 1, str. 1828. 
Premda postoje sofisticirani argumenti koji dovode u pitanje Kantorowiczeve teorijske postavke, primjerice Schmidt koja smatra da optužbe protiv pokreta slobodnog prava u ovom kontekstu ne treba olako odbaciti jer je "sam život" postao središnji slogan nacionalsocijalista ${ }^{235}$, uvjerljiviji su argumenti koji se koriste u obranu Kantorowicza, pritom osobito mislimo na argumente koje je iznijela Grosswald Curran u vezi s tim. Shvaćanje prava kao normativnog i postojanje slobodnog prava, neovisnog o državi u suprotnosti su s temeljima nacionalsocijalističke vizije prava.

$\mathrm{Na}$ kraju je važno istaknuti da Kantorowicz nikad nije napisao opsežnije djelo o metodologiji i pravnoj teoriji. ${ }^{236}$ Tako da nije ponudio, kako to ističe Schmidt, pravu alternativu "tradicionalnoj dogmatskoj pravnoj znanosti". ${ }^{237}$ U tome se možda i krije razlog zašto sam pokret nije imao odlučujući utjecaj na njemačku pravnu znanost. ${ }^{238} \mathrm{Za}$ ostvarenje ideja koje su podržavali, poput pravne sigurnosti i pravednosti bez sustava i "dogmatskih elemenata", nisu ponudili zadovoljavajući odgovor za njihovo ostvarenje. ${ }^{239}$

\section{LITERATURA}

Auer, M., Der Kampf um die Wissenschaftlichkeit der Rechtswissenschaft - Zum 75. Todestag von Kantorowicz, Zeitschrift für europäisches Privatrecht, br. 4, 2015. str. 773-805.

Bix, B., Radbruch's Formula and Conceptual Analysis, The American Journal of Jurisprudence, vol. 56, 2011. str. 45-57.

Bulygin, E., Essays in legal philosophy, Oxford University Press, Oxford, New York, 2015.

Dubber, M. D., Judicial Positivism and Hitler's Injustice, Columbia Law Review, vol. 93, 1993., str. 1807-1831.

Fasso, G., Istorija filozofije prava, CID, Univerzitet Mediteran, Podgorica, 2007.

Foulkes, A. S., On the German Free Law School (Freirechtsschule), ARSP: Archiv für Rechts- und Sozialphilosophie / Archives for Philosophy of Law and Social Philosophy, vol. 55, br. 3,1969., str. 367-417.

235 Schmidt, op. cit. u bilj. 6, str. 135.

236 Auer, op. cit. u bilj. 220, str. 782.

237 Schmidt, op. cit. u bilj. 37, str. 446.

238 Ibid.

239 Ibid., str. 465. 
Gnavius Flavius, The Battle for Legal Science, German Law Journal, vol. 12, br. 11, 2011., str. 2005-2030.

Goodhart, A. L., Introduction, u Kantorowicz, H., The Definition of Law (Campbell, A. H. ed.), 1980., str. XI-XXIV.

Grosswald Curran, V., Fear of Formalism: Indications from the Fascist Period in France and Germany of Judicial Methodology's Impact on Substantive Law, Cornell International Law Journal, vol. 35, br. 1, 2001, str. 101-187.

Grosswald Curran, V., Rethinking Hermann Kantorowicz: Free Law, American Legal Realism and the Legacy of Anti Formalism, $\mathrm{u}$ Riles, A. (ed.), Rethinking the Masters of Comparative Law, Hart, Oxford, Portland, 2001., str. 66- 91.

Grosswald Curran, V., Romantic Common Law, Enlightened Civil Law: Legal Uniformity and the Homogenization of the European Union, Columbia Journal of European Law, vol. 7, 2001., str. 63-126.

Guastini, R., Sintaksa prava, Naklada Breza, Zagreb, 2016.

Hart, H. L. A., Reviewed Work: The Definition of Law by Hermann Kantorowicz, A.

H. Campbell, A. L. Goodhart, The Philosophical Review, vol. 69, br. 2, 1960., str. 270-272.

Herget, J. E.; Wallace, S., The German Free Law Movement as the Source of American Legal Realism, Virginia Law Review, vol. 73, br. 2, 1987., str. 399-455.

Joerges, C., History as Non-History: Points of Divergence and Time Lags between Friedrich Kessler and German Jurisprudence, The American Journal of Comparative Law, vol. 42, br. 1, 1994. str. 163-193.

Kantorowicz Carter, F., Gustav Radbruch and Hermann Kantorowicz: Two Friends and a Book - Reflections on Gnaeus Flavius' Der Kampf um die Rechtswissenschaft (1906), German Law Journal, vol. 7, br. 7, 2006., str. 657-700.

Kantorowicz, H., Some Rationalism About Realism, Yale Law Journal, vol. 43, 1934., str. 1240-1253.

Kantorowicz, H., Borba za pravnu nauku, Dosije, Beograd, 2006.

Kantorowicz, H, The Definition of Law, Campbell, A. H. (ed.), Octagon Books, New York, 1980.

Kaufmann, A., National Socialism and German Jurisprudence from 1933-1945, Cardozo Law Review, vol. 9, 1988., str. 1629-1649.

Kelly, J. M., A Short History of Western Legal Theory, Oxford University Press, Oxford, 2010.

Kelsen, H., Pure Theory of Law, The Lawbook Exchange, LTD., Clark, New Jersey, 2005. 
Kelsen, H., Čista teorija prava: uvod u problematiku pravne znanosti, Naklada Breza, Zagreb, 2012.

Krešić, M., Primjena Kantorowiczeve i Hartove defincije prava na međunarodno pravo, Pravni vjesnik, vol. 29, br. 3-4, 2013., str. 119-138.

Lubben, S. J., Chief Justice Traynor's Contract Jurisprudence and the Free Law Dilemma: Nazism, the Judiciary, and California's Contract Law, Southern California Interdisciplinary Law Journal, vol. 7, 1988., str. 81- 132.

Mertens, T., But was It Law, German Law Journal, vol. 7, br. 2, 2006., str. 191- 198.

Osrečak, J., Poredbenopravni prikaz načela savjesnosti i poštenja, Zagrebačka pravna revija, vol. 3, br. 1, 2014., str. 53-77.

Ott, W.; Buob, F., Did Legal Positivism Render German Jurists Defenceless During the Third Reich?, Social \& Legal Studies, vol. 2, br. 1, 1993., str. 91-104.

Padjen, I.; Pokrovac, Z.; Opatić, N., Zabrana uskrate pravosuđa i uskrate prava: pristup hrvatskim problemima, u Pokrovac, Z.; Padjen, I. (ur.), Zabrana uskrate pravosuda i prava: 11. njemačko-hrvatski pravnički simpozij, Split, 27.-28. travnja 2007. / Justiz- und Rechtsverweigerungsverbot: 11. deutsch-kroatisches Juristensymposium, Split, 27.-28. April 2007, Pravni fakultet u Splitu, Split, 2010., str. 231-281.

Paulson, S. L., Formalism, 'Free Law', and the 'Cognition' Quandary: Hans Kelsen's Approaches To Legal Interpretation, The University of Queensland Law Journal, vol. 27, br. 2, 2008, str. 7-39.

Paulson, S. L., On the Background and Significance of Gustav Radbruch's Post-War Papers, Oxford Journal of Legal Studies, vol. 26, br. 1, 2006., str. 17-40.

Paulson, L. S., Lon L. Fuller, Gustav Radbruch, and the "Positivist Theses", Law and Philosophy, vol. 13, br. 3, 1994., str. 313-359.

Pokrovac, Z., Slobodno stvaranje prava. Hermann U. Kantorowicz i slobodnopravni pokret, Naklada Breza, Zagreb, 2018.

Radbruch, G., Filozofija prava, Naklada Breza, Zagreb, 2019.

Reimann, M., Nineteenth Century German Legal Science, Boston College Law Review, vol. 31, 1990., str. 837-897.

Schmidt, K. I., Law, Modernity, Crisis: German Free Lawyers, American Legal Realists, and the Transatlantic Turn to 'Life', 1903-1933, German Studies Review, vol. 39, br. 1, 2016., str. 121-140.

Schmidt, K. I., Der "Formalismus-Mythos" im deutschen und amerikanischen Rechtsdenken des frühen 20. Jahrhunderts, Der Staat, vol. 53, 2014., str. 445-473.

Sebok, A. J., Misunderstanding Positivism, Michigan Law Review, vol. 93, 1995., str. $2054-2132$. 
Sfekas, S. J., A Court Pure and Unsullied: Justice in the Justice Trial at Nuremberg, University of Baltimore Law Review, vol. 46, br. 3, 2017., str. 457-521.

Sfekas, S. J., The Enabler, The True Believer, The Fanatic: German Justice in The Third Reich, The Journal Jurisprudence, vol. 26, 2015., str. 189-229.

Somek, A., From Kennedy to Balkin: Introducing Critical Legal Studies from a Continental Perspective, University of Kansas Law Review, vol. 42, 1994., str. 759-783.

Winkler, V., Review Essay - Some Realism about Rationalism: Economic Analysis of Law in Germany, German Law Jorunal, vol. 6, br. 6, 2005., str. 1033-1044; doi: 10.1017/S2071832200014097

Zimmermann, A., Legislating Evil: The Philosophical Foundations of the Nazi Legal System, International Trade \& Business Law Review, vol. 13, 2010., str. 221241.

Zubović, A., Primjena trgovačkih običaja, Zbornik Pravnog fakulteta Sveučilišta u Rijeci, vol. 27, br. 1, 2006., str. 307-343.

\section{MREŽNI IZVORI}

Hermann Kantorowicz, https://www.uni-kiel.de/grosse-forscher/index.php?nid=kantorowicz\&lang=e. (1. kolovoza 2019.)

Kantorowicz, Hermann, International Encyclopedia of the Social Sciences. Encyclopedia.com, https://www.encyclopedia.com (15. kolovoz 2019.)

Somek, A., Legal Science as a Source of Law: A Late Reply by Puchta to Kantorowicz (November 13, 2012). U Iowa Legal Studies Research Paper No. 13-7. Available at SSRN: https://ssrn.com/abstract=2175235 or http://dx.doi.org/10.2139/ ssrn.2175235, str. 1-24 (1. kolovoza 2019.) 


\section{Summary}

\section{Ivana Tucak*}

\section{HERMANN U. KANTOROWICZ'S LEGAL THOUGHT AND THE ERA OF NATIONAL SOCIALISM}

This paper is aimed at challenging the role of the anti-formalist criticism of law by Hermann Kantorowicz, one of the most prominent members of the Free Law Movement (Freirechtsbewegung) in German legal theory during the era of national socialism. Members of that movement highlighted the principle of justice and the necessity of the existence of legal gaps (lacunae), and invited judges to abandon legal positivism/formalism and replace it with a system which would take account of the social circumstances in which a legal dispute arises. A number of contemporary authors have questioned whether Kantorowicz and other members of the movement actually made what German judges did in Nazi Germany in the period from 1933 to 1945 possible or, in other words, whether they set the grounds for the "legal terror" which characterized that period. The paper is divided into two parts. The first part examines the fundamental concepts of law and legal science, and the role of judges, conveyed in Kantorowicz's book The Battle for Legal Science. The second part explores a number of arguments published in distinguished legal journals, which support or contest the allegations against Kantorowicz and the Free Law Movement.

Key words: free law, natural law, legal positivism, jurisprudence of concepts, legal gaps

\footnotetext{
* Ivana Tucak, Ph. D., Associate Professor, Faculty of Law, Josip Juraj Strossmayer University of Osijek, Stjepana Radića 13, Osijek; itucak@pravos.hr;

ORCID ID: orcid.org/0000-0001-9694-2315
} 